IZA DP No. 9698

Deconstructing Theories of Overeducation in Europe:

A Wage Decomposition Approach

Seamus McGuinness

Konstantinos Pouliakas

February 2016

Forschungsinstitut zur Zukunft der Arbeit Institute for the Study of Labor 


\title{
Deconstructing Theories of Overeducation in Europe: A Wage Decomposition Approach
}

\author{
Seamus McGuinness \\ Economic and Social Research Institute (ESRI) \\ and IZA \\ Konstantinos Pouliakas \\ CEDEFOP, University of Aberdeen \\ and IZA
}

Discussion Paper No. 9698

February 2016

IZA
P.O. Box 7240
53072 Bonn
Germany

Phone: +49-228-3894-0

Fax: +49-228-3894-180

E-mail: iza@iza.org

Any opinions expressed here are those of the author(s) and not those of IZA. Research published in this series may include views on policy, but the institute itself takes no institutional policy positions. The IZA research network is committed to the IZA Guiding Principles of Research Integrity.

The Institute for the Study of Labor (IZA) in Bonn is a local and virtual international research center and a place of communication between science, politics and business. IZA is an independent nonprofit organization supported by Deutsche Post Foundation. The center is associated with the University of Bonn and offers a stimulating research environment through its international network, workshops and conferences, data service, project support, research visits and doctoral program. IZA engages in (i) original and internationally competitive research in all fields of labor economics, (ii) development of policy concepts, and (iii) dissemination of research results and concepts to the interested public.

IZA Discussion Papers often represent preliminary work and are circulated to encourage discussion. Citation of such a paper should account for its provisional character. A revised version may be available directly from the author. 
IZA Discussion Paper No. 9698

February 2016

\section{ABSTRACT \\ Deconstructing Theories of Overeducation in Europe: A Wage Decomposition Approach ${ }^{*}$}

This paper uses data from the Cedefop European Skills and Jobs (ESJ) survey, a new international dataset of adult workers in $28 \mathrm{EU}$ countries, to decompose the wage penalty of overeducated workers. The ESJ survey allows for integration of a rich, previously unavailable, set of factors in the estimation of the effect of overeducation on earnings. Oaxaca decomposition techniques are employed to uncover the extent to which the overeducation wage penalty can be attributed to either (i) human capital attributes, (ii) job characteristics, (iii) information asymmetries, (iv) compensating job attributes or (v) skill needs of jobs. Differences in human capital and job-skill requirements are important factors in explaining the wage premium. It is found that asymmetry of information accounts for a significant part of the overeducation wage penalty for tertiary education graduates, whereas job characteristics and low skill content of jobs explain most of the wage gap for medium-qualified employees. Little evidence is found in favour of equilibrium theories of skills matching and compensating wage differentials. The paper thus highlights the need for customised policy responses (e.g. career guidance; policies to raise job quality) to tackle overeducation.

JEL Classification: J24, J31, J70, I26

Keywords: $\quad$ overeducation, skills, mismatch, wages, decomposition

Corresponding author:

Konstantinos Pouliakas

CEDEFOP

Europe 123

Thessaloniki (Pylaia) 57001

Greece

E-mail: Konstantinos.Pouliakas@cedefop.europa.eu

\footnotetext{
* The views expressed in the paper are solely the authors' and do not necessarily represent those of the European Centre for the Development of Vocational Training (Cedefop). The usual disclaimer applies. The authors would like to thank Professor Kostas Mavromaras (Flinders University, South Australia) and participants at the CEDEFOP/IZA workshop on skills and skill mismatch (29-30 October, Thessaloniki, Greece) for their useful comments and insights.
} 


\section{Introduction}

The literature on skill mismatch has grown significantly over the years, where skills mismatch is usually defined either in terms of excess or deficient qualifications and skills possessed by individuals relative to job-skill requirements. ${ }^{1}$ Evidence from several advanced economies has shown that skill mismatch is a widespread phenomenon, typically affecting about one third of the higher educated employed population. Several research studies have also cautioned in recent years that as a result of the 2008 economic crisis, there has been a tendency towards higher overqualification rates across Europe (Pouliakas, 2012; ILO, 2014). Studies of skill mismatch tend to focus on one of two central measures (a) overskilling which describes the phenomena whereby workers are unable to use a range of their skills and abilities in their current job and (b) overeducation, which describes the phenomena whereby workers have acquired a level of schooling in excess of what is required to either get or do a job. The literature to date suggests that there is a less than perfect correlation between overeducation and overskilling and that both phenomena tend to have quite distinct implications for workers. Overeducation tends to be associated with a large penalty on pay but a lower impact on job satisfaction, whereas overskilling tends to affect pay less but is associated with much lower levels of job satisfaction (McGuinness \& Sloane, 2011; Mavromaras et al., 2013a). In this study we are interested in decomposing the impacts of qualification mismatch on worker pay and, consequently, our focus is exclusively on overeducation which has consistently been associated with a substantial pay penalty.

A number of studies have attempted to uncover the potential determinants of various forms of mismatch, by assessing the degree to which the wage penalties associated with overeducation or overskilling adjust when different controls for job/individual worker characteristics are added to model specifications (McGuinness and Sloane, 2011). Other studies have measured the degree to which any measured disadvantage declines in models that control for unobserved ability (Bauer, 2002). However, to date, no studies have applied decomposition techniques to assess the extent to which observed differentials, in either wage or job satisfaction premiums, between matched and mismatched workers relate to (a)

\footnotetext{
${ }^{1}$ Cedefop (2010) provides clear-cut definitions and discusses the differences between the terms "over(under)education" and "over- (under-)skilling", all of which tend to be referred to (somewhat confusingly) in literature under the overarching term 'skill mismatch'.
} 
differences in the endowments of human capital and job-related variables (b) differences in the returns to given characteristics and (c) unobserved effects.

The aim of this study is to decouple the influence of the aforementioned factors on the wage penalty of overeducated workers in the $28 \mathrm{EU}$ member states. The paper will measure the extent to which the raw pay penalty experienced by overeducated workers relates to observable differences in human capital, job characteristics, job-skill requirements, worker preferences and the quality of job search information. Not only will this approach quantify the proportion of the pay gap that can be attributed to particular theoretical perspectives, but it will also allow us to draw important policy conclusions regarding potential measures for reducing the incidence of overeducation. For example, the research will provide an indication as to the extent to which overeducation rates are likely to respond to policies targeted at the accumulation of skills, compared to improved job content or facilitating a better work life balance.

In order to meet its research goal, the study explores new data from the Cedefop European skills and jobs survey (ESJ), carried out in 2014 by the European Centre for the Development of Vocational Training (Cedefop). The value added of the new dataset is that it contains novel information on many important correlates of interest for skill mismatch at European level, including the information, motives and constraints that individuals had at the time of job search and a battery of questions on the nature of tasks and skills required by individuals' jobs. Section 2 of the paper provides a review of the literature on the magnitude of wage penalties related to overeducation and factors that may account for the differences in pay between workers with matched and excess qualifications. Section 3 describes the new dataset and key variables used for the purposes of the empirical analysis. Section 4 explains the empirical methodology employed while section 5 provides an extensive discussion of the empirical findings. Section 6 concludes.

\section{Literature review}

The overeducation literature has mushroomed in recent times and has become a key issue of policy importance (Quintini, 2011; Pouliakas, 2012). As the focus of this paper relates to the degree to which the wage penalty associated with overeducation can be explained by observable differences between matched and overeducated workers, we will focus on the 
literature related to both the robustness of the overeducation pay penalty and the potential explanatory variables that should be included in any wage decomposition.

\subsection{The magnitude and robustness of wage penalty estimates}

Comprehensive surveys and meta-analyses of the wealth of empirical estimates have highlighted that there are important negative wage and welfare consequences of overeducation on individual employees (Hartog, 2000; McGuinness, 2006; Cedefop, 2010; Leuven and Oosterbeek, 2011; Pouliakas, 2012; Sattinger, 2012).

The majority of the studies have confirmed two stylized facts in relation to the impact of overeducation on pay, as suggested initially by Sicherman and Galor (1991). First, overeducated workers suffer from a wage penalty in relation to matched individuals with the same level of education, whereas they earn a premium over their matched colleagues in the same job. Relative to matched workers with similar levels of schooling, the average wage penalty associated with overeducation has been estimated, on the basis of a dummy variable in a standard wage regression, at around 15\% (McGuinness, 2006). Another approach (known as the ORU approach) breaks down the educational level into three constituent components (Over-, Required- and Under-education) (Duncan and Hoffman, 1981). Based on this methodology, Groot and Maasen van der Brink (2000) produce meta-analytical estimates of an average rate of return of $5.6 \%$ for attained years of education. Importantly, the return to surplus $(3 \%)$ or deficient $(-1.5 \%)$ years of education is significantly lower compared to the comparable return for required years of education (7.8\%). The evidence thus suggests that although the overeducated work below their potential due to some productivity ceiling (related to inferior skills and abilities or to particular firm and institutional characteristics), there is still some benefit to be enjoyed from the extra years of education (Rumberger, 1987).

A key issue in the literature is that the above determinants and consequences of mismatch have been identified mostly in cross-sectional datasets or short time-series of graduate cohorts. Thus, it has been argued that perceived mismatches on the basis of the above data are partly a statistical artefact that reflects unobserved labour market sorting due to differences in individual abilities/skills within educational categories (Bauer, 2002; McGuinness, 2003; Frenette, 2004). The plausibility of this statement has been heightened in recent years, given the rapid expansion in tertiary education graduate rates across many 
developed countries. Overeducation may therefore not be genuinely related to an underutilisation of skills or abilities, since the additional investment in education may simply compensate for the lack of ability of individuals who appear to be mismatched (Chevalier, 2003; Green and Zhu, 2010).

For instance, Mavromaras et al. (2010) and Sloane (2014) argue, on the basis of estimates from an Australian longitudinal dataset (HILDA), that the magnitude of many coefficients based on cross-sectional data appear to be questionable. Using panel data methods that control for unobserved individual heterogeneity identifies unbiased estimates of the effect of skill mismatch, although concerns about the limited within-group variance in the incidence of mismatch also raises some doubts that the fixed effects estimates are themselves unbiased (Mavromaras et al, 2013b).

Thus, the evidence on the reliability of cross-sectional estimates of the overeducation pay penalty remains somewhat mixed. While the wage impacts fall substantially when estimated within a panel framework that controls for unobserved time-invariant influences, such models may themselves generate biased estimates of the coefficients of variables, such as overeducation, that move slowly over time (ibid., 2013b). Consequently, we conclude that while there exists some debate with regard to the magnitude of the overeducation pay penalty, the differential itself represents a genuine measure of disadvantage experienced by overeducated workers in the labour market.

\subsection{What are the potential determinants of overeducation?}

It is important that any attempt to decompose the wage effects associated with overeducation includes a choice of covariates consistent with both economic theory and existing empirical studies. A number of theoretical frameworks have been used to conceptualise overeducation including (a) Human Capital Theory, (b) the Job Competition Model, (c) Assignment theory and (d) Occupational mobility theory and models of job search. Human Capital Theory (HCT) (Becker, 1964; Mincer, 1974) predicts that workers will always earn their marginal product, implying that there should be no under-utilization of human capital in the labour market and that overeducation will not exist in equilibrium. However, overeducation may still be observed in a world where the predictions of HCT hold, if earnings and continuous human capital accumulation are imperfectly measured i.e. overeducation 
may simply be a statistical artefact arising as a consequence of an omitted variables problem (McGuinness, 2006). Specifically, the overeducation pay penalty may simply reflect lower levels of total human capital among workers who, despite having higher than average levels of formally acquired human capital (schooling), have lower levels of human capital acquired in the workplace (e.g. non-formal training and informal on-the-job learning), the latter imperfectly measured within the data. Therefore, on the basis of the HCT model, any attempt to decompose the overeducation pay penalty should include sufficient controls and measures for human capital acquired through both formal schooling and workplace learning/experience.

Thurow's Job Competition Model (Thurow, 1975) emphasizes the importance of job availability and argues that workers are allocated to a fixed distribution of jobs with individuals investing in education in order to preserve their place in the jobs queue. Once an individual reaches the top of the queue they are allocated to a job, so their wage will be predetermined solely by the productivity characteristics of the job in question, with overeducation occurring where the skill requirements of the allocated position are below those acquired by the worker. Similarly, assignment models (Sattinger, 1993; Sattinger and Hartog, 2013) also stress the importance of job distribution; however, the job allocation process is no longer a lottery as utility maximization guides workers to choose certain jobs over others and wages are determined by a hedonic price equation that accounts for both job and worker characteristics. Therefore, both the job competition and assignment interpretations of the labour market point to the importance of taking into account controls for productivity-relevant job characteristics and other vacancy externalities (e.g. the availability of suitable job opportunities in the labour market) when decomposing the overeducation pay penalty.

Theories of career mobility (Sicherman and Galor, 1991) suggest that some workers choose an initially mismatched post that enables them to acquire the necessary skills, through onthe-job training and work experience, which will enable them to achieve more rapid career progression in the future. Alternatively, proponents of matching theories of job search (Jovanavic, 1970) suggest that overeducation is largely a consequence of poor information and, over time, workers will realize their error and achieve improved matches through repeated job search. Other authors have hypothesised that mismatch may be a consequence 
of workers trading off overeducation and lower pay for other job attributes, such as job security, for which they have a stronger preference (McGuinness and Sloane, 2011). Therefore, these frameworks suggest that overeducation is a temporary phenomenon, driven by either strategic behaviour or imperfect information, suggesting that worker preferences and beliefs should also be included within the decomposition framework.

\section{Data and descriptive statistics}

\subsection{The Cedefop European Skills and Jobs (ESJ) survey}

The Cedefop ESJ survey is a state-of-the-art survey of adult employees (aged 24-65) carried out in the 28 member states of the European Union, collecting information on the match of their skills with the skill needs of their jobs. It was financed and developed by the European Centre for the Development of Vocational Training (Cedefop), in collaboration with a network of experts on skills, the OECD and Eurofound (Cedefop, 2015). The aim of the survey is to help inform the development of European policies on initial and continuing education and training and employment policies. To do so, it seeks to understand how individuals' qualifications and skills are matched (or not) to the changing skill demands and complexities of their jobs. The survey also looks at the extent to which employees' skills are developed and used in their workplaces over time.

A mixed methodology approach ensured that the data collected provided a representative sample of the adult working age population in each of the EU28 member states. The survey was carried out using quota sampling by the survey company Ipsos MORI and its network partners in each country between 7 March and 26 June 2014. In total, 48,676 respondents from different demographic groups took part either by telephone $(9,154$ employees) or online interviewing (39,522 employees). ${ }^{2}$ In most EU countries about 1000-1500 employees were effectively interviewed, although the sample varies between countries. The sample was augmented to 4000 observations in the case of five large EU labour markets, such as Germany, France, Poland, UK, Spain, 3000 cases for Italy, and 2000 cases in Greece and Finland, while

\footnotetext{
2 The questionnaire was translated into the national languages of the EU countries using a strict translation protocol, managed by Ipsos MORI. Prior to administering the survey, extensive cognitive and pilot tests took place to validate the content and validity of the survey instrument. For details, see Cedefop (2015).
} 
500 individuals were surveyed by telephone in each of the three smallest countries (Malta, Cyprus and Luxembourg). ${ }^{3}$

The survey asked respondents a series of questions designed to assess the extent to which their qualifications and skills are at the level needed to be hired for and to do their job. The key contribution of the new survey is that it takes a longitudinal perspective, with some of these questions asked several times, referring to distinct time periods, enabling the dynamic analysis of skill mismatch of EU employees. The survey thus offers the first comparable evidence of the dynamic evolution of skill mismatch of employees across all $28 \mathrm{EU}$ countries. It also allows researchers to take into account the persistency or initial state of skill mismatch affecting individuals over time.

Given that the new survey focused on the issue of skill mismatch, it contains contextual information that was not readily available in previous datasets. For example, in addition to a standard set of control vairables (e.g. age, gender, level of education, firm size, type of contract, economic sector, occupation) the survey collected data on the micro/macroeconomic motives and constraints that influence individuals' job choice; determinants of skill accumulation in their jobs, focusing on both non-formal and informal continuing vocational training; experience of work-based learning as part of initial education and training; whether individuals embarked on occupation and/or geographic mobility prior to accepting their current job; and the changing complexity of workers' tasks in their jobs. In addition, the survey permits the definition and measurement of several types of skill mismatch, including educational mismatch and mismatch in terms of employees' skill levels. Furthermore, the survey collected data on the gross monthly earnings of adult workers in the 28 countries.

The inclusion of this rich set of variables and the availability of an international sample for the analysis of overeducation is a marked improvement relative to previous empirical studies, which have either used rich databases albeit from single countries, or have relied on sometimes problematic panel data estimation techniques.

\footnotetext{
${ }^{3}$ To control for any erratic variance in the mode of sampling, the empirical analysis has included as an additional explanatory variable a dummy variable that identifies whether a given observation was approached via online or telephone interviewing.
} 


\subsection{Key variables and summary statistics}

The study utilises the full sample of adult employees, aged between 24 and 65, in all 28 European member states, corresponding to 48,676 cases. To analyse the wage consequences of overeducation among European workers, two separate measures of educational mismatch were derived as a first step in the analysis.

In the ESJ survey respondents were asked about the typical qualifications and skills needed for their jobs. Specifically, the survey asked respondents to assess both the level of qualifications needed to get their job if someone would apply for their job today, in addition to the level of skills needed to do their job. This was done to investigate whether there is a discrepancy between the qualifications needed for recruitment purposes and the level of education that constitutes a genuine prerequisite for performing the necessary tasks in a job. Particularly in weak labour markets with high unemployment rates, employers may inflate recruitment criteria to filter the best candidates, or they may afford to deliberately hire individuals with higher education as a means of hedging against greater economic uncertainty (Bulmahn and Krakel, 2002). In either case individuals are induced to acquire higher qualifications to be hired in a more competitive labour market, fostering credentialism, even though the jobs for which they are recruited for may eventually require lower qualifications and skills than they possess.

The measure of overeducation derived, and used as the main dependent variable in the wage regressions of the paper, is based on a direct comparison of the highest qualification level of individuals (translated to conventional ISCED levels) with the qualification level reported by themselves as necessary to actually do their current job. ${ }^{4}$ This variable should represent a more reliable measure of mismatch between acquired schooling and job content, whereas the alternative measure based on education necessary to get the job is likely to be confounded by credentialism and is less directly related to actual job content.

\footnotetext{
${ }^{4}$ However, for the sake of robustness, the empirical analysis in section 5 has also taken into account the measure of qualification mismatch based on the level of education needed so that people can be hired in their current jobs. No significant changes to the main findings are observed, given the very high correlation (Pearson correlation coefficient $=0.8$ ) of the two variables.
} 
In 2014, about $33 \%$ of adult job holders in the EU sample believed that a tertiary education degree is required so that they can perform their job, the majority (40\%) responded that their job could be performed with a medium-level qualification while $21 \%$ stated that a low level or no qualifications at all suffice. Comparing the educational requirement with the own qualification of employees, the survey confirms that a substantial share of the European workforce is employed in jobs that need a different (higher or lower) level of qualifications than their own for performing them. In 2014, total qualification mismatch affected, on average, $29 \%$ of the European adult working population, comprising of $17 \%$ who were overqualified and 12\% underqualified. About 1 in $4(24 \%)$ tertiary educated workers (and 16\% of medium-qualified employees) in Europe are found to be overeducated for their jobs.

Figure 1 shows that, on average, overeducation in the EU is more prevalent among youngeraged employees, females and individuals who were outside of the labour market (unemployed or inactive) prior to accepting their current employment. It is also higher among tertiary education graduates, particularly those from certain fields of study, such as humanities, languages and arts and other social sciences. Rates of overeducation are also significantly different depending on the characteristics of jobs. In particular, they are higher for individuals employed in smaller-sized firms and in less skill-intensive occupations (e.g. elementary jobs, service and market sales workers) and for those in non-standard contract jobs (part time, informal, temporary agency contracts).

\section{[INSERT FIGURE 1 ABOUT HERE]}

To breakdown the differences in earnings between overeducated and matched workers, a measure of hourly earnings of adult employees has been derived as follows. Individuals were initially asked to report how much is their gross monthly earnings from their job (before deductions or credits of tax and national insurance). About $70 \%$ of the whole sample provided an earnings figure, but the remaining $30 \%$ either refused $(24.5 \%)$ to disclose their earnings or did not know (5.5\%). For the latter two groups the survey included a follow-up question, which allowed respondents to identify in which of four national-specific income bands their own monthly earnings belong to. ${ }^{5}$ In case of a valid response, the mid-point of the respective

\footnotetext{
${ }^{5}$ For each country four respective income bands were defined, namely \{below lowest quartile, between lowest quartile and median, between median and highest quartile, above highest quartile\}, based on reliable country-
} 
income band has been used as a proxy of a respondent's monthly earnings. In this manner, the sample used for the analysis contains positive wage values for about $83 \%$ of the original sample of adult employees. Nevertheless, around $17 \%$ of the sample either refused to provide their earnings data in both income questions of the ESJ survey, or did not know or answer altogether.

Following the aforementioned procedure, it was observed that the wage variable was distorted by the existence of a number of outliers in the sample (potentially because several respondents provided an estimate of their annual rather than monthly earnings). To correct for the observed skewness, the variable was therefore capped both at the bottom and at the top of the distribution. In particular, the bottom $1 \%$ and the top $5 \%$ of the distribution were dropped completely from the sample. Following the exclusion of possible outliers from the analysis, the distribution of the wage variable and its summary moments were observed to be compatible to those identified from other reliable European data sources containing information on salary income of EU employees (e.g. EU SILC). For instance, the mean monthly earnings of employees in the EU28 block are equal to approximately $2300 \mathrm{EUR}$, ranging from above 4000 EUR in Denmark or 3000 EUR in Luxembourg, Finland and Sweden to 430 euros in Bulgaria. As a final step the monthly earnings of adult workers were converted to hourly earnings by dividing by the usual average weekly hours worked (multiplied by 4.33 since the variable on hours includes paid and unpaid overtime hours).

\section{[INSERT TABLE 1 ABOUT HERE]}

Table 1 displays differences in average hourly wages between overeducated and matched EU adult employees. The mean monthly earnings of the overeducated is equal to 2141 EUR whereas the respective figure for matched employees is 2360 EUR, a wage penalty of 219 EUR per month for the former group. However, the latter are employed for an extra 1.5 hours per week (38.2 as opposed to 36.8 hours), which explains why there is a smaller difference in mean hourly earnings between the two groups. There is greater skewness in the earnings distribution of matched employees, resulting in a 2 EUR per hour premium in median hourly wages. The table also indicates that the wage difference between the two groups is mostly

specific data (e.g. latest waves of EU-SILC survey or national LFS datasets). More details are available at Cedefop (2015). 
driven by tertiary education and recent graduates, males, individuals returning back to the labour market after a period of inactivity, recipients of on-the-job training and those in jobs with non-indefinite contracts and low skill content.

\section{Empirical methodology}

The associations shown in Figure 1 and Table 1 highlight the importance of taking into account a number of factors that are correlated with the incidence of overeducation, when estimating the ceteris paribus effect of the latter on individual earnings. A multivariate regression analysis has therefore been employed in the paper that controls for the effect of several key characteristics, consistent with theory, in the estimation of earnings functions that contain the overeducation dummy as the main explanatory variable of interest.

In particular, the empirical analysis follows a standard decomposition framework as outlined by Oaxaca (1973) and Blinder (1973). ${ }^{6}$ The procedure requires first the estimation of separate earnings functions for individuals in paid employment who are either overeducated or have a qualification level matched to the requirement of their job. The wage gap between the two groups is then deconstructed into a part that is attributable to differences in the mean productive characteristics (the explained part) and a part that is due to different returns to such characteristics (the unexplained part). In this manner it becomes possible to detect the extent to which several observable characteristics contribute to wage differences between the overeducated and matched and how much of the wedge can be attributed to discriminatory practices or other unobserved influences.

Mincer-type earnings functions are first fitted for each group (overeducated and matched) as follows:

$$
\ln \mathbf{W}_{i}=\mathbf{H}_{i} \boldsymbol{\beta}+\mathbf{Z}_{i} \boldsymbol{\gamma}+\mathbf{C}_{i} \boldsymbol{\delta}+\boldsymbol{\varepsilon}_{i}
$$

where $\ln W_{i}$ are the log hourly earnings of individual $i(i=1, \ldots, N), \boldsymbol{H}_{i}$ is a vector of individual human capital attributes which affect earnings, $\mathbf{Z}_{i}$ is a vector of characteristics describing a range of other theory consistent explanatory variables (such as job characteristics, job search information and

\footnotetext{
${ }^{6}$ The analysis was replicated using the amended methodologies proposed by Neumark (1988) and Oaxaca and Ransom (1994), showing very similar results to the ones discussed in the paper.
} 
preferences), $\boldsymbol{C}$ are country dummies and $\varepsilon_{i}$ is a Gaussian random error term. The terms $\boldsymbol{B}, \boldsymbol{\gamma}, \boldsymbol{\delta}$ are regression parameters that capture the marginal returns of the characteristics contained in the vectors $\boldsymbol{H}, \mathbf{Z}, \boldsymbol{C}$ and will be estimated on the basis of the ESJ sample. Robust standard errors of the regression coefficients clustered at the country level are calculated for statistical inference purposes.

The total difference in the mean wages of the two groups can then be decomposed in the conventional Oaxaca manner as follows:

$$
\bar{W}_{m}-\bar{W}_{\text {mis }}=\left(\bar{H}_{m}-\bar{H}_{m i s}\right) \hat{\beta}_{m}+\left(\bar{Z}_{m}-\bar{Z}_{m i s}\right) \hat{\gamma}_{m}+\left(\hat{\gamma}_{m}-\hat{\gamma}_{m i s}\right) \bar{Z}_{m i s}+\left(\hat{\beta}_{m}-\hat{\beta}_{m i s}\right) \bar{X}_{m i s}
$$

where the first part of equation (2) (i.e. the 'explained' or 'endowment' part) reflects the component of the average wage difference between the two groups attributed to differences in the means of the explanatory variables, which are in turn weighed by the estimated coefficients of the matched equation. It measures the relative importance of observable differences in human capital, job characteristics, preferences etc. between the two sets of workers. The second term (i.e. the 'unexplained' part) refers to the part of the wage gap that arises because of the differential manner with which the labour market rewards the characteristics of overeducated and matched employees. In this respect, it provides an indication of the extent to which mismatched employment imposes productivity-related constraints on the return to observable characteristics.

The models are estimated first for the whole sample and then separately for individuals with a different level of education (i.e. ISCED category), given that tertiary education graduates are more likely to be overeducated as opposed to those with a medium-level qualification. Furthermore, a stepwise approach has been followed, which first allows for an empirical specification that only incorporates standard demographic and human capital characteristics (e.g. age, gender, education attainment level, previous labour market status, years of employer tenure, non-formal and informal training in job) and subsequently takes into account standard job characteristics (e.g. private sector, size of workplace, type of contract, tasks required in job, promotion prospects) and other important factors (e.g. job search motives of workers, skill needs of job). In terms of the theoretical perspectives, the variables on education and training capture the impact of Human Capital theory, while the information on job characteristics and skill requirements relate closely to the predictions of both the Job Competition Model and Assignment Theory. 
Furthermore, the novel information provided in the survey with regards to the motives for job choice among individuals permits this study to put additional theories of overeducation under scrutinity. These questions were asked retrospectively and rank the importance of a series of factors for individuals choosing their current job. As these responses should, theoretically, predate the point before they commenced their current job, reverse causality becomes less of a concern. These retrospective variables enable us to assess the relative importance of compensating wage effects and, specifically, the extent to which individuals valued aspects of the job such as reputation, work-life balance and intrinsic benefits. The importance of Job Mobility Theory is captured by variables which measure the extent to which the job was chosen on the basis of its value for career progression or as a channel for gaining work experience. Finally, the relative importance of prior information and, therefore, the quality of the job signal, is captured by a range of prior response variables that reflect the level of information that the respondent had with respect to the jobs' benefits and skill requirements.

\section{Empirical results}

\subsection{Estimation of earnings regressions}

Tables 2-4 display ordinary least squares coefficients following estimation of the main earnings function, shown in equation (1), based on a sample of adult employees from all 28 EU member states. Table 2 displays the estimated coefficients for the whole sample, whereas Tables 3 and 4 show the effects broken down by level of education attainment, first for those with tertiary level qualifications and subsequently for individuals with an upper secondary/non-tertiary degree. The estimated coefficients describe the mean conditional (proportional) effect of the explanatory variables on individuals' hourly earnings, ceteris paribus.

\section{[INSERT TABLES 2-4 ABOUT HERE]}

As shown in Table 2, overeducated workers suffer from a $22 \%$ wage penalty relative to matched employees, when controlling for age, gender, level of education and their labour market status prior to job entry. The figure falls to $19 \%$ when an augmented Mincer earnings function is estimated. In this case the estimation takes into account that the overeducated have lower average levels of job-specific skills relative to the matched, due to fewer years of seniority and less participation in non-formal and informal training. 
The size of the penalty is robust to the inclusion of variables that act as proxies for the match between employees' skills and the skill needs of their job, namely whether their skills exceed current job requirements (overskilled) or are deficient relative to the optimal productivity threshold (skill gap). ${ }^{7}$ This implies that the lower wages of overeducated workers are independent of the fact that some of them may have inferior or superior skills than needed by their jobs. It is thus important to consider explanations other than those that focus on skills matching for understanding the source of the overeducation wage gap.

Job characteristics, such as whether an employee's workplace is in the private sector or of larger size, or the nature of complexity and autonomy of the job tasks, are important predictors of adult workers' wages. However, the overeducation wage penalty, at $18 \%$, is quite robust to the inclusion of such variables.

Another part of the lower earnings of overqualified workers can be attributed to their placement in jobs with lower skill content, namely jobs that place a low degree of importance on cognitive, digital and soft skills. Accounting for different levels of skill needs by jobs leads to a marked reduction in the size of the regression coefficient on the overeducation dummy. But even for individuals with the same human capital features, employed in jobs of similar characteristics and skill intensity, it is observed that the overeducated still earn $13.8 \%$ lower wages than those with matched qualifications. This result suggests that it is not the possession of excess labour market skills that determine earnings per se, but the possession of excess skills relevant to actual job requirements.

The full specification of the estimated equations reveals that part of the significant wage penalty of overqualified workers also reflects the quality and relevance of the information available to them (e.g. via career guidance and counselling or other forms of labour market intelligence) as part of the job search process. It is evident that overeducated individuals who do not select their jobs on the basis of their suitability with their own skills and qualifications, or because of imperfect knowledge of their pay and benefits, are more likely to have lower

\footnotetext{
${ }^{7}$ The equation and decomposition analysis has included as explanatory variables both the quality of the skill match at the time of entry into an individual's job and at the time of the survey. Either of the variables acting as proxies of skills matching is statistically insignificant in earnings equations, once other characteristics of individuals and jobs are taken into account.
} 
mean wages. By contrast, placing a higher premium on job security, an employer's reputation or because of a job's proximity to the household exerts a negative pull on wages.

When examining determinants of earnings for adult workers with different levels of education attainment, as shown in Tables $\mathbf{3}$ and $\mathbf{4}$, it is found that the overeducation wage penalty is somewhat higher (ranging between 15-24\%, depending on the specification) for highly educated graduates and lower (between 8-18\%) for medium-qualified graduates. The overeducation wage penalty is robust to differences between higher education graduates in their subject of study, given that specific fields such as economics, engineering and medicine are associated with higher average earnings. Tertiary graduates employed in jobs where their skills are not fully utilised (overskilled) suffer from a $2 \%$ wage deficit relative to those with matched skills; however, the regression coefficient of the overeducation variable is not affected, which confirms that it is independent of the variation in the match of workers' general level of surplus skills. By contrast, it is clear that part of the wage difference between overeducated and matched workers is driven by the skill needs of their jobs and individual job search motives.

Interestingly, the factors that weigh more heavily in explaining the lower wages of overeducated graduates with medium-level qualifications are their lower stock of job-specific human capital (measured in both years of employer tenure and participation in non-formal and informal training) and the fact that they are employed in jobs with a lower skill content. Nevertheless, the OLS estimates show the combined impact of both endowment and coefficient effects related to specific groups of variables on the overeducation pay premium. In order to separate out the relative importance of variations in the amount of each attribute held by overeducated and matched workers, we must adopt a decomposition approach as discussed in the next section.

\subsection{Decomposition analysis}

\subsubsection{Endowments differences between matched-overeducated workers}

In terms of the decomposition analysis, the base case is individuals who are matched, so the decomposition algorithm explains the pay premium to being matched relative to the overeducated group. The full specification, as shown in the final columns of Tables 2-4, is used when estimating the respective wage equations for the subsamples of matched and mismatch 
employees, namely one that takes into account human capital and job characteristics, as well as the skill content of jobs and individuals' job search motives.

As is evident in Table 5, differences in endowments can explain about $28 \%$ of the raw overeducation gap in a sample of employees who hold at least an upper secondary qualification. ${ }^{8}$ In a similar spirit, the difference in observable characteristics is found to account for about $31 \%$ of the raw wage premium in the medium-educated model, whereas they account for $43 \%$ in the model focused on tertiary education graduates. Nevertheless, despite the richness of our data, the majority of the overeducation raw pay gap remained unexplained in all three models.

\section{[INSERT TABLE 5 ABOUT HERE]}

Dealing firstly with the results of the total sample, Table 6 shows that differences in job characteristics and job skill requirements are the most important factors in explaining the wage advantage of matched workers, however, motivation variables and country level fixed effects also play a marked role. Turning specifically to the human capital results, the data shows that individuals with matched qualifications (the reference group) are found to have higher mean wages mainly because of their higher average age and seniority. ${ }^{9}$ Furthermore, the observed raw pay premium is reduced by the higher tertiary education attainment of the overeducated, but widens due to their lower levels of on-the-job training and their greater incidence of past unemployment episodes.

With respect to job characteristics, the lower wages of the overeducated can be partially attributed to the fact that they are more frequently employed under a temporary contract and in very small-sized workplaces than the matched. Furthermore the mismatched are also less likely to have been promoted in their jobs. Finally, when turning to job-skill requirements, the overeducated are, on average, employed in less skill intensive jobs, in particular jobs that

\footnotetext{
${ }^{8}$ When undertaking the Oaxaca decomposition analysis we have excluded individuals with a low level education from the sample due to the fact that, by definition, they cannot be classified as overeducated workers. If they are not excluded, the wage regression restricted only to overeducated workers is run on a sample of mediumand high educated individuals, whereas the respective regression on the matched sample also includes those with low education.

${ }^{9}$ Exactly why age is important, as opposed to job tenure is unclear. The result suggests that part of the pay gap may relate to the accumulation of general labour market experience; nevertheless, cohort effects, whereby the relative availability of quality positions within firms has fallen as educational attainment has risen, also represents a potential explanation.
} 
do not require an advanced literacy or ICT skill level to be performed, which depresses their wages by acting as a productivity threshold. The absence of high literacy requirements within the job has the most substantial impact on the overeducation pay penalty.

The empirical wage decompositions further highlight the critical role of information and, to a lesser extent, of career concerns, in sorting or not individuals into well-matched jobs. In particular, overeducated adult employees are less likely to have selected their jobs because they are a suitable match for their qualifications and skills, or because of knowledge of their pay and benefits, and this negatively impacts the wedge between their wages and those of matched workers. The latter were instead more inclined to select their job because of their career development opportunities, or for the promise of gaining some work experience. Some, though limited, evidence is found to suggest that individuals may be willing to accept jobs below their qualification level as a trade-off for them being closer to their home.

Overall, in the model containing the whole sample of individuals holding at least upper secondary qualifications, human capital differences account for around $5 \%$ of the observed raw pay gap and standard job characteristics explain $9 \%$ of the gap. Two blocks of explanatory variables, previously unaccounted for in most empirical analyses, account for the largest share of the overeducation wage penalty. In particular, the skill intensity of jobs explain $18 \%$ of the observed wage gap, while individuals' job search motives account for a further $11 \%$.

In terms of the sample of tertiary education graduates, overall, it is observed that human capital endowments weigh more heavily relative to the whole sample, explaining $16 \%$ of the raw wage differential. Job motives follow in significance, accounting for $9 \%$ of the overeducation pay gap, although the combination of job characteristics and of the importance of skills in jobs explains $14 \%$ of the total raw wage difference. This highlights the critical role of landing a skill-intensive job as a safeguard for graduates' earnings, especially if they enter into jobs demanding lower qualifications than their own.

In terms of the specific human capital effects, the impact of age and employer tenure still represents the largest single impacts, however, they are less pronounced for tertiary education graduates relative to the average, as is the impact of a previous unemployment spell. Importantly, overeducated employees with a tertiary level qualification are found to be less likely to have graduated from an Economics and Business degree as part of their studies, 
which tends to raise the pay gap. Overeducated graduates also have a greater tendency to be graduates from Humanities subjects and are less prone to Engineering and Education science courses, which also contribute to their lower wages relative to those of matched employees.

Turning to job characteristics, as in the total sample, overeducated tertiary graduates are recipients of lower mean hourly wages due to the fact that they are more frequently employed in smaller-sized workplaces and in less skill-intensive jobs, associated with fewer opportunities for promotion. They are also found to be less likely to select jobs on the basis that they are a suitable match for their skills and qualifications. Moreover, overeducated tertiary workers tend to put greater emphasis on the proximity of their job to their home, which impacts negatively on hourly wages.

Finally, we decompose the earnings of medium skilled workers. A crucial difference between the high- and medium-educated models is the large role played by country level fixed effects in the latter decomposition. The results indicate that the pay premium enjoyed by matched medium skill workers is substantially reduced as a consequence of their higher relative concentration in lower wage economies. Such a large negative fixed effect makes the interpretation of the results in the medium skill decomposition more complicated. Nevertheless, they suggest that job characteristics and skill requirements generally outweigh differences in human capital endowments or other important factors, in terms of explaining wage differences between the overeducated and those with matched qualifications.

Ignoring the size of the endowment effects and concentrating on their relative impact, it is clear from the decomposition results that overeducated medium-qualified workers tend to be in jobs that do not require high levels of literacy or ICT skills and this can account for a substantial amount of their raw pay gap. They are also more likely to have temporary contracts and to be in jobs in which they fail to get a promotion. Among human capital endowments it is evident that seniority plays a dominant role, given that the higher earnings of matched workers is attributed to their additional years of employer tenure and to the lower incidence of past unemployment spells. The matched are also found to have higher wages because of greater participation in training courses during their work hours. Those among them that selected their jobs on the basis of the pay and benefits offered, or because of their 
favourable career prospects, also benefit from higher hourly wages relative to their overeducated counterparts.

\section{[INSERT TABLE 6 ABOUT HERE]}

\subsubsection{Unexplained wage differences between matched and overeducated workers}

Table 7 focuses on the part of the difference in wages between matched and overeducated workers that is unexplained, attributed either to a discrepancy in the shift coefficients or to differential market valuations of the average characteristics of the two groups of employees. In particular, the table shows differences in the estimated regression coefficients of the matched and overeducated groups, weighted by the average characteristics of the overeducated workers, a component that could reflect labour market discrimination against those who enter into jobs requiring lower qualifications than their own.

Overall, around $70 \%$ of the raw wage difference in the total sample and in the sample of medium-qualified employees remains unexplained, while a smaller share $(57 \%)$ is unaccounted for in the high-educated model. On the whole overeducated workers are found to benefit from higher wage returns to their productive characteristics, although this is not true for overeducated tertiary education graduates and is driven by the significant wage returns enjoyed by those with medium-level education. Matched workers are also found to have higher absolute mean wages than the overeducated across all education levels, as indicated by the positive intercept terms, suggesting that the bulk of the unexplained wage component may be driven by factors not controlled for in our models.

Having a higher level of education is valued more for individuals that enter into jobs that are a good match for their qualifications within graduate labour markets. The higher mean wages of matched tertiary educated workers relative to the overeducated are amplified due to the higher returns to age and training participation of the former. Being in a multi-site workplace environment, or selecting the job because it suits one's credentials or yields higher pay and benefits, disproportionately benefits those in jobs with matched qualifications. By contrast, overeducated tertiary graduates who were driven, when selecting their job, by career progression possibilities, enjoy a higher wage increment in comparison to the matched. 
Furthermore, individuals in overeducated posts receive higher financial returns for each extra year of employer seniority, regardless of level of education. Each additional year of age is also rewarded more highly for medium-qualified overeducated employees. The male-female wage gap for those with a medium-level education is also smaller among individuals with matched qualifications relative to the overeducated.

Therefore, while the bulk of the unexplained wage premium is related to higher average wages among matched workers which may, in turn, be attributable to omitted variables, there is some evidence of differential returns to observable characteristics that appear to vary according to the level of mismatch. Medium skilled overeducated workers enjoy higher returns to human capital characteristics relative to their matched counterparts; however, these positive wage effects are more than outweighed by a large average overeducation pay penalty. Conversely, matched graduates earn a slight premium due to higher returns to human capital characteristics, with the vast majority of the unexplained premium relating to a large average wage effect, which may also be driven by factors not available in the data.

\section{[INSERT TABLE 7 ABOUT HERE]}

\section{Conclusions}

Following a conventional Oaxaca decomposition analysis, the empirical findings in this paper reveals that about one third of the observed wage premium to being matched relative to being overeducated can be explained by differences in the endowments of the two groups. Among graduates, a larger part (43\%) of the pay gap is explained, with human capital differences, job requirements and informational constraints affecting workers at the time of job search, accounting for the largest part of the explained gap. These results confirm that while individual and job characteristics are important in explaining the overeducation pay penalty of graduates, the job selection process and, in particular, taking time to ensure that the job matches your skill set, has a big pay-off. The reduction of information asymmetries among graduates with regards to available job opportunities therefore appears to be a key policy response to overcoming the problem of graduate overeducation (McGuiness et al., 2015). From a theoretical perspective, graduate overeducation appears consistent with aspects of human capital theory, assignment theory and the signalling model, so important lessons can be learnt from each perspective in terms of reducing the incidence of 
overeducation. The finding that overeducation is consistent with a signalling problem is more novel. From a policy perspective the signalling result highlights the importance of effective guidance and counselling, provision of incentives for job mobility and perhaps of prolonged job search to facilitate the better matching of the skills of tertiary graduates with their jobs.

Among medium-educated workers, ignoring country level fixed effects, the largest explained effects relate to job characteristics, such as the fact that the overeducated are more likely to be in temporary contracts and are located in smaller firms and in jobs without promotion prospects. Differences in job skill requirements are also an important factor, with overeducated workers being paid less as they tend to be in jobs that only require a basic level of skills. Raising job quality, or increasing job flexibility, would therefore appear to constitute a more effective policy response for mitigating overeducation experienced by individuals with a medium-level education. As overeducation among the medium educated appears to be related to job-specific productivity ceilings which limit wage growth, the observed outcomes appear more consistent with both the job competition and assignment interpretations of the labour market.

It is likely that the relative contribution of the various theoretical frameworks and, therefore, the most appropriate recommendations with respect to policy change will vary across countries and more research is needed in this respect. A crucial aspect of the existing results highlight the fact that overeducation among medium skilled workers is less common within lower wage economies, suggesting that structural factors are a key determinant of mismatch. The results suggest that the relative demand for intermediate labour declines as economies grow, perhaps due to the impact of skill biased technological change, resulting in higher rates of overeducation among medium skilled workers who are potentially being "bumped down" into lower quality jobs.

Finally, it is important to note that despite the use of a highly detailed data set, the majority of the overeducation pay penalty could not be explained in terms of endowment effects. More research is certainly required if we are to fully understand both the determinants and consequences of overeducation in the labour market. 


\section{References}

Bauer T. (2002), "Educational Mismatch and Wages: A Panel Analysis", Economics of Education Review, 21, 221-229.

Becker, G.S. (1964). Human Capital. New York: Columbia University Press.

Blinder, A.S. (1973). "Wage Discrimination: Reduced Form and Structural Estimates". Journal of Human Resources, Vol. 8 No 4, pp. 436-455.

Bulmahn, G. and Kräkel, M. (2002). "Overeducated Workers as an Insurance Device”, LABOUR, Vol. 16, No. 2, p. 383-402.

Cedefop (2010). The skill matching challenge: analysing skill mismatch and policy implications. Luxembourg: Publications Office.

http://www.cedefop.europa.eu/EN/Files/3056 en.pdf

Cedefop (2015), Skills, qualifications and jobs in the EU: the making of a perfect match?, Cedefop reference series No. 103, Luxembourg: Office for the Official Publications of the European Union. http://www.cedefop.europa.eu/en/publications-andresources/publications/3072

Chevalier, A. (2003). "Measuring Over-education". Economica, Vol.70, No. 279, p. 509-531.

Duncan, G. and Hoffman, S. (1981). 'The incidence and wage effects of overeducation'. Economics of Education Review, 1: 75-86.

Frenette, M. (2004). "The overqualified Canadian graduate: the role of the academic program in the incidence, persistence, and economic returns to overqualification". Economics of Education Review, Vol. 23, No. 1, p. 29-45.

Green, F. and Zhu, Y. (2010). 'Overqualification, job dissatisfaction, and increasing dispersion in the returns to graduate education'. Oxford Economic Papers, 62: 740-763.

Groot, W. and Maassen van den Brink, H. (2000). Overeducation in the labor market: a metaanalysis. Economics of Education Review, Vol. 19, No. 2, p. 149-158.

Hartog, J. (2000). 'Over-education and earnings: Where are we, where should we go?'. Economics of Education Review, 19: 131-147.

ILO (2014), Skill mismatch in Europe: Statistics Brief, Geneva: International Labour Organisation.

Jovanovic, B. (1970). "Job Matching and the Theory of Turnover", Journal of Political Economy, 87, 972-990.

Leuven, E. and Oosterbeek, H. (2011). 'Overeducation and mismatch in the labor market'. In Erik Hanushek, F. Welch (eds.): Handbook of the Economics of Education, Elsevier Science, Vol. 4, 283 - 326.

Mavromaras, K., McGuinness, S., O'Leary, N., Sloane, P. and Fok, Y. (2010), 'The problem of overskilling in Australian and Britain'. The Manchester School, 78: 219-241.

Mavromaras, K., Mahuteau, S., Sloane, P. and Wei, Z. (2013a). 'The effect of overskilling dynamics on wages'. Education Economics, 21: 281-303.

Mavromaras, K,. McGuinness, S, O'Leary, N., Sloane, P, \& Wei, Z. (2013b). “Job Mismatches and Labour Market Outcomes: Panel Evidence on Australian University Graduates", Economic Record, Vo. 89 (286), pp. 382-395.

McGuinness, S. (2003). "Graduate overeducation as a sheepskin effect: evidence from Northern Ireland", Applied Economics, Vol. 35, No. 5, p. 597-608.

McGuinness, S. (2006). Overeducation in the labour market. Journal of Economic Surveys, Vol. 20, No 3, p. 387-418. 
McGuinness, S. \& Sloane, P. J. (2011). "Labour Market Mismatch Among UK Graduates: An Analysis Using Reflex Data", Economics of Education Review, Vol. 30 (1), 130-145.

McGuinness, S., Whelan, A. \& Bergin, A. (2015). "Recruitment Methods and Educational Provision Effects on Graduate Overeducation and Overskilling", STYLE working paper D5.4.

Mincer, J.A. (1974). Schooling, Experience and Earnings. New York: Columbia University Press.

Neumark, D. (1988). "Employers' discriminatory behavior and the estimation of wage discrimination." Journal of Human Resources, Volume 23, No. 3, pp. 279-95.

Oaxaca, R.L. (1973). "Male-Female Wage Differentials in Urban Labor Markets", International Economic Review, Vol. 14 No. 3, pp. 693-709.

Oaxaca, R.L. and Ransom, M.R. (1994). "On discrimination and the decomposition of wage differentials," Journal of Econometrics, Elsevier, Vol. 61 No.1, pp. 5-21.

Pouliakas, K. (2012). 'The skill mismatch challenge in Europe', Ch. 6 in: Employment and Social Developments in Europe 2012. Luxembourg: Publications Office of the European Union.

Quintini, G. (2011). "Over-qualified or Under-skilled: A review of the existing literature". OECD Social, Employment and Migration working papers No.121.

Rumberger, R. (1987). 'The impact of surplus schooling on productivity and earnings'. Journal of Human Resources, Vol. 22, pp. 24-50.

Sattinger, M. (1993). "Assignment models of the distribution of earnings", Journal of Economic Literature, No 31, p. 831-880.

Sattinger, M. (2012). Qualitative Mismatches. Hanover (Ma.): Now Publishers.

Sattinger, M. and Hartog, J. (2013). 'Nash bargaining and the wage consequences of educational mismatches'. Labour Economics, 23: 50-56.

Sicherman, N. and Galor, O. (1991). 'Overeducation in the labor market'. Journal of Labor Economics, 9: 101-122.

Sloane, P.J. 2014. "Overeducation, skill mismatches, and labor market outcomes for college graduates," IZA World of Labor, Vol. 88. http://wol.iza.org/articles/overeducation-skillmismatches-and-labor-market-outcomes-for-college-graduates/long

Thurow, L.C. (1975). Generating inequality. New York: Basic Books. 
Figure 1 Overeducation by population groups, \% of adult employees, 2014, EU28

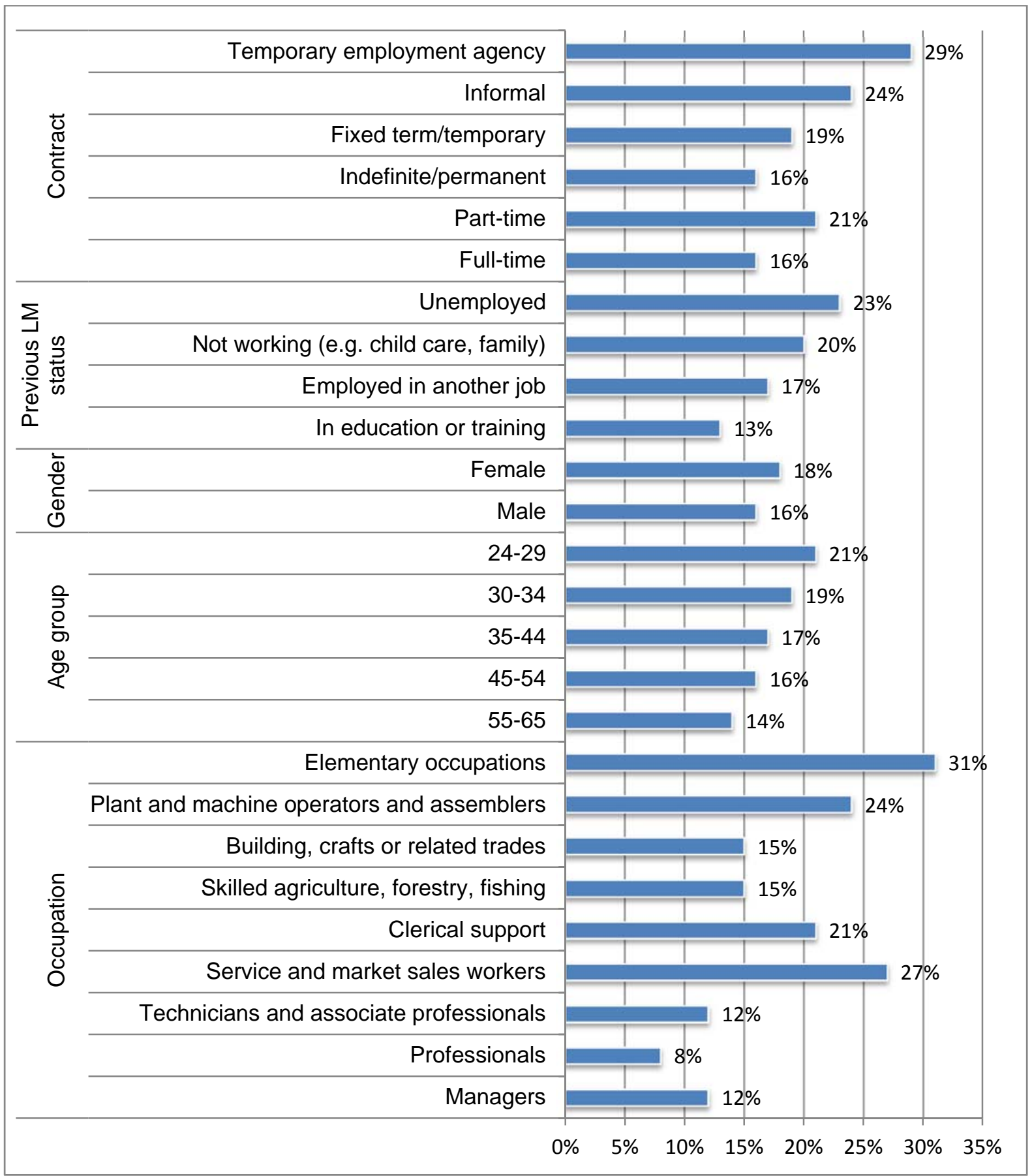

Source: Cedefop European Skills and Jobs (ESJ) survey 
Table 1 Mean (s.d) hourly earnings (EUR) by overeducation status, 2014, EU28

\begin{tabular}{|l|c|c|}
\hline & Overeducated & Matched \\
\hline Distribution of earnings & & \\
\hline Mean log(hourly wage) & $2.28(0.85)$ & $2.42(0.81)$ \\
\hline Median & 10.39 & 12.31 \\
\hline $1^{\text {st }}$ quartile & 6.06 & 7.31 \\
\hline $3^{\text {rd } \text { quartile }}$ & 15.19 & 18.07 \\
\hline By level of education attainment & $16.62(64.20)$ & $18.35(23.26)$ \\
\hline High (ISCED 5-6) & $14.51(26.54)$ & $14.62(22.88)$ \\
\hline Medium (ISCED 3-4) & & \\
\hline By gender & $16.47(66.62)$ & $15.61(24.95)$ \\
\hline Female & $14.72(21.46)$ & $16.20(21.62)$ \\
\hline Male & & \\
\hline By age groups & $14.95(66.89)$ & $15.03(24.26)$ \\
\hline $24-39$ & $16.33(25.65)$ & $16.18(22.90)$ \\
\hline $40-54$ & $15.72(31.62)$ & $17.39(21.68)$ \\
\hline 55-65 & & \\
\hline By previous labour market status & $16.01(61.20)$ & $15.84(19.98)$ \\
\hline Employed & $15.44(26.35)$ & $14.85(21.02)$ \\
\hline Self-employed & $15.97(29.26)$ & $16.85(25.61)$ \\
\hline Education and training & $14.04(23.61)$ & $14.34(23.42)$ \\
\hline Unemployed & $15.57(23.51)$ & $18.45(47.43)$ \\
\hline Inactive & & \\
\hline By training incidence & $16.11(26.22)$ & $16.69(22.12)$ \\
\hline Training mostly or only during work hours: Yes & $15.27(60.84)$ & $15.29(24.15)$ \\
\hline Training mostly or only during work hours: No & & \\
\hline By type of contract & $16.25(53.73)$ & $16.11(22.78)$ \\
\hline Indefinite & $11.00(18.67)$ & $13.73(19.24)$ \\
\hline Fixed term & $12.79(18.95)$ & $23.08(64.63)$ \\
\hline Temporary agency & $17.77(41.20)$ & $14.14(20.05)$ \\
\hline No formal contract & $16.07(36.28)$ & $18.82(36.71)$ \\
\hline Other & & \\
\hline By skill content of job & $16.68(23.95)$ & $17.44(24.06)$ \\
\hline Advanced literacy skills needed in job & $17.55(27.03)$ & $18.33(23.66)$ \\
\hline Advanced ICT skills needed in job & & \\
\hline $\begin{array}{l}\text { Advanced soft skills (e.g. problem solving, } \\
\text { communication skills) needed in job }\end{array}$ & $16.28(23.17)$ \\
\hline Source Cedfop) & & \\
\hline
\end{tabular}

Source: Cedefop European skills and jobs (ESJ) survey 
Table 2: OLS estimates of wage equation, all adult employees, 2014, EU28

\begin{tabular}{|c|c|c|c|c|c|c|}
\hline & $\begin{array}{c}\text { (1) } \\
\text { Basic HC }\end{array}$ & $\begin{array}{c} \\
\text { Augmented } \\
\text { HC }\end{array}$ & $\begin{array}{c}\text { (3) } \\
\text { Skill } \\
\text { mismatch }\end{array}$ & $\begin{array}{l}\text { (4) } \\
\mathrm{Job}\end{array}$ & $\begin{array}{c}\text { (5) } \\
\text { Skill needs }\end{array}$ & $\begin{array}{c}\text { (6) } \\
\text { Motives }\end{array}$ \\
\hline overeducated & $\begin{array}{c}-0.22 * * * \\
(0.012)\end{array}$ & $\begin{array}{c}-0.19 * * * \\
(0.010)\end{array}$ & $\begin{array}{c}-\mathbf{- 0 . 1 9} * * * \\
(0.010)\end{array}$ & $\begin{array}{c}-0.18 * * * \\
(0.010)\end{array}$ & $\begin{array}{c}-0.14 * * * \\
(0.011)\end{array}$ & $\begin{array}{c}-0.12 * * * \\
(0.011)\end{array}$ \\
\hline age & $\begin{array}{c}0.03 * * * \\
(0.006)\end{array}$ & $\begin{array}{c}0.02^{* * *} \\
(0.005)\end{array}$ & $\begin{array}{c}0.02 * * * \\
(0.005)\end{array}$ & $\begin{array}{c}0.02 * * * \\
(0.005)\end{array}$ & $\begin{array}{c}0.02 * * * \\
(0.005)\end{array}$ & $\begin{array}{c}0.02 * * * \\
(0.005)\end{array}$ \\
\hline agesq & $\begin{array}{c}-0.00 * * * \\
(0.000)\end{array}$ & $\begin{array}{c}-0.00 * * * \\
(0.000)\end{array}$ & $\begin{array}{c}-0.00^{* * *} \\
(0.000)\end{array}$ & $\begin{array}{c}-0.00 * * * \\
(0.000)\end{array}$ & $\begin{array}{c}-0.00 * * * \\
(0.000)\end{array}$ & $\begin{array}{c}-0.00^{* * *} \\
(0.000)\end{array}$ \\
\hline male & $\begin{array}{c}0.12^{* * *} \\
(0.014)\end{array}$ & $\begin{array}{c}0.12^{* * *} \\
(0.015)\end{array}$ & $\begin{array}{c}0.12^{* * *} \\
(0.015)\end{array}$ & $\begin{array}{c}0.10^{* * *} \\
(0.014)\end{array}$ & $\begin{array}{c}0.10^{* * *} \\
(0.014)\end{array}$ & $\begin{array}{c}0.09 * * * \\
(0.014)\end{array}$ \\
\hline medisced & $\begin{array}{c}0.21^{* * *} \\
(0.032)\end{array}$ & $\begin{array}{c}0.20 * * * \\
(0.029)\end{array}$ & $\begin{array}{c}0.20 * * * \\
(0.029)\end{array}$ & $\begin{array}{c}0.19 * * * \\
(0.028)\end{array}$ & $\begin{array}{c}0.14^{* * *} \\
(0.026)\end{array}$ & $\begin{array}{c}0.15^{* * *} \\
(0.027)\end{array}$ \\
\hline highisced & $\begin{array}{c}0.47 * * * \\
(0.042)\end{array}$ & $\begin{array}{c}0.45 * * * \\
(0.038)\end{array}$ & $\begin{array}{c}0.45 * * * \\
(0.038)\end{array}$ & $\begin{array}{c}0.42 * * * \\
(0.036)\end{array}$ & $\begin{array}{c}0.34 * * * \\
(0.034)\end{array}$ & $\begin{array}{c}0.34^{* * *} \\
(0.035)\end{array}$ \\
\hline preveduc & $\begin{array}{l}0.03^{* *} \\
(0.014)\end{array}$ & $\begin{array}{c}-0.03 * * * \\
(0.010)\end{array}$ & $\begin{array}{c}-0.03 * * * \\
(0.010)\end{array}$ & $\begin{array}{c}-0.03 * * * \\
(0.010)\end{array}$ & $\begin{array}{c}-0.03 * * * \\
(0.010)\end{array}$ & $\begin{array}{c}-0.02 * * \\
(0.011)\end{array}$ \\
\hline prevunemp & $\begin{array}{c}-0.14^{* * *} \\
(0.018)\end{array}$ & $\begin{array}{c}-0.12 * * * \\
(0.015)\end{array}$ & $\begin{array}{c}-0.12 * * * \\
(0.015)\end{array}$ & $\begin{array}{c}-0.11^{* * *} \\
(0.015)\end{array}$ & $\begin{array}{c}-0.10^{* * *} \\
(0.015)\end{array}$ & $\begin{array}{c}-0.09 * * * \\
(0.014)\end{array}$ \\
\hline prevoth & $\begin{array}{c}-0.07 * * * \\
(0.015)\end{array}$ & $\begin{array}{c}-0.08 * * * \\
(0.015)\end{array}$ & $\begin{array}{c}-0.08^{* * *} \\
(0.015)\end{array}$ & $\begin{array}{c}-0.07 * * * \\
(0.015)\end{array}$ & $\begin{array}{c}-0.06 * * * \\
(0.014)\end{array}$ & $\begin{array}{c}-0.06^{* * *} \\
(0.017)\end{array}$ \\
\hline emptenure & & $\begin{array}{c}0.01^{* * *} \\
(0.002)\end{array}$ & $\begin{array}{c}0.01^{* * *} \\
(0.002)\end{array}$ & $\begin{array}{c}0.01 * * * \\
(0.002)\end{array}$ & $\begin{array}{c}0.01 * * * \\
(0.002)\end{array}$ & $\begin{array}{c}0.01^{* * *} \\
(0.002)\end{array}$ \\
\hline emptenuresq & & $\begin{array}{c}-0.00 * * * \\
(0.000)\end{array}$ & $\begin{array}{c}-0.00 * * * \\
(0.000)\end{array}$ & $\begin{array}{l}-0.00 * \\
(0.000)\end{array}$ & $\begin{array}{l}-0.00^{*} \\
(0.000)\end{array}$ & $\begin{array}{l}-0.00^{*} \\
(0.000)\end{array}$ \\
\hline train_courses_in & & $\begin{array}{c}0.07 * * * \\
(0.009)\end{array}$ & $\begin{array}{c}0.07^{* * *} \\
(0.009)\end{array}$ & $\begin{array}{c}0.05 * * * \\
(0.008)\end{array}$ & $\begin{array}{c}0.04 * * * \\
(0.008)\end{array}$ & $\begin{array}{c}0.03 * * * \\
(0.007)\end{array}$ \\
\hline train_courses_out & & $\begin{array}{c}0.04^{* * *} \\
(0.011)\end{array}$ & $\begin{array}{c}0.04^{* * *} \\
(0.011)\end{array}$ & $\begin{array}{c}0.04 * * * \\
(0.010)\end{array}$ & $\begin{array}{c}0.03^{* * *} \\
(0.010)\end{array}$ & $\begin{array}{c}0.03 * * * \\
(0.010)\end{array}$ \\
\hline train_ojt & & $\begin{array}{l}0.02 * * \\
(0.008)\end{array}$ & $\begin{array}{l}0.02 * * \\
(0.009)\end{array}$ & $\begin{array}{c}0.01 \\
(0.008)\end{array}$ & $\begin{array}{c}0.00 \\
(0.008)\end{array}$ & $\begin{array}{c}0.01 \\
(0.007)\end{array}$ \\
\hline overskilled & & & $\begin{array}{c}-0.00 \\
(0.006)\end{array}$ & $\begin{array}{c}-0.01 \\
(0.006)\end{array}$ & $\begin{array}{c}-0.01 \\
(0.005)\end{array}$ & $\begin{array}{c}-0.00 \\
(0.005)\end{array}$ \\
\hline skilldef & & & $\begin{array}{c}-0.00 \\
(0.000)\end{array}$ & $\begin{array}{c}-0.00 \\
(0.000)\end{array}$ & $\begin{array}{c}-0.00 \\
(0.000)\end{array}$ & $\begin{array}{c}0.00 \\
(0.000)\end{array}$ \\
\hline temporary & & & & $\begin{array}{c}-0.05^{* * *} \\
(0.013)\end{array}$ & $\begin{array}{c}-0.05^{* * *} \\
(0.012)\end{array}$ & $\begin{array}{c}-0.06^{* * *} \\
(0.012)\end{array}$ \\
\hline informal & & & & $\begin{array}{c}-0.03 \\
(0.023)\end{array}$ & $\begin{array}{c}-0.02 \\
(0.024)\end{array}$ & $\begin{array}{c}-0.01 \\
(0.027)\end{array}$ \\
\hline multisite & & & & $\begin{array}{c}0.02 * * * \\
(0.007)\end{array}$ & $\begin{array}{c}0.02 * * * \\
(0.007)\end{array}$ & $\begin{array}{l}0.02 * * \\
(0.007)\end{array}$ \\
\hline private & & & & $\begin{array}{l}0.03^{* *} \\
(0.011)\end{array}$ & $\begin{array}{c}0.02 * \\
(0.011)\end{array}$ & $\begin{array}{c}0.02 * \\
(0.010)\end{array}$ \\
\hline size10to49 & & & & $\begin{array}{c}0.06 * * * \\
(0.011)\end{array}$ & $\begin{array}{c}0.06 * * * \\
(0.011)\end{array}$ & $\begin{array}{c}0.05^{* * *} \\
(0.012)\end{array}$ \\
\hline size50to99 & & & & $\begin{array}{c}0.07 * * * \\
(0.013)\end{array}$ & $\begin{array}{c}0.07 * * * \\
(0.013)\end{array}$ & $\begin{array}{c}0.06 * * * \\
(0.011)\end{array}$ \\
\hline size100to249 & & & & $\begin{array}{c}0.12 * * * \\
(0.013)\end{array}$ & $\begin{array}{c}0.11 * * * \\
(0.012)\end{array}$ & $\begin{array}{c}0.10^{* * *} \\
(0.013)\end{array}$ \\
\hline
\end{tabular}


size250to499

$0.14^{* * *} \quad 0.14^{* * *} \quad 0.13^{* * *}$

size500

$\begin{array}{lll}(0.015) & (0.016) \quad(0.017)\end{array}$

$0.16^{* * *}$

$0.16^{* * *}$

$0.15 * * *$

jobnrout

(0.018)

(0.017)

(0.017)

$-0.00$

$-0.01$

$-0.00$

joblearn

(0.010)

(0.010)

(0.009)

$-0.01 *$

$-0.03^{* * *}$

$-0.03 * * *$

jobaut

(0.008)

(0.008)

(0.010)

$0.03 * * *$

$0.03^{* * *}$

$0.02 * *$

(0.008)

(0.008)

(0.007)

jobteam

$-0.02 * * *$

$-0.02 * *$

$-0.02 * *$

(0.008)

(0.008)

(0.008)

role_promoted

$0.09 * * *$

$0.07 * * *$

$0.07 * * *$

(0.014)

(0.014)

$0.06^{* * *}$

(0.014)

advlit

(0.008)

$0.06 * * *$

advnum

$0.02 * *$

(0.008)

(0.008)

$0.01 *$

modict

$0.08^{* * *}$

(0.008)

(0.009)

$0.07 * * *$

$0.10 * * *$

(0.008)

advict

(0.017)

$0.10 * * *$

highiskill

$0.03^{* * *}$

(0.018)

(0.007)

$0.02 * *$

factor_suitskills

(0.007)

$0.01 * * *$

(0.001)

factor_experience

$-0.01 * * *$

(0.001)

factor_security

$-0.01 * * *$

(0.002)

factor_career

$0.01^{* * *}$

(0.002)

factor_reputation

$-0.00 * * *$

(0.001)

$0.02 * * *$

factor_benefits

(0.002)

factor_closehome

$-0.01 * * *$

(0.001)

0.00

(0.002)

factor_intrinsic

$0.01 * * *$

factor_worklife

(0.002)

Country dummies

Constant

$\begin{array}{cc}\text { YES } & \text { YES } \\ 1.62 * * * & 1.80 * * * \\ (0.133) & (0.118) \\ 35,522 & 35,423 \\ 0.59 & 0.59\end{array}$

YES

YES

YES

YES

Observations

(0.122)

$1.73^{* * *}$

1.69***

$1.66 * * *$

R-squared

35,315

(0.110)

(0.106)

(0.114)

NB: Robust

0.59

35,315

35,315

31,277

0.61

Source: Cedefop European skills and job (ESJ) survey 
Table 3: OLS estimates of wage equation, higher educated adult employees, 2014, EU28

\begin{tabular}{|c|c|c|c|c|c|c|}
\hline & $\begin{array}{c}\text { (1) } \\
\text { Basic HC }\end{array}$ & $\begin{array}{c}\text { (2) } \\
\text { Augmented } \\
\text { HC }\end{array}$ & $\begin{array}{c}\text { (3) } \\
\text { Skill } \\
\text { mismatch }\end{array}$ & $\begin{array}{l}(4) \\
J o b\end{array}$ & $\begin{array}{c}\text { (5) } \\
\text { Skill needs }\end{array}$ & $\begin{array}{c}\text { (6) } \\
\text { Motives }\end{array}$ \\
\hline overeducated & $\begin{array}{c}-0.24 * * * \\
(0.014)\end{array}$ & $\begin{array}{c}-0.22 * * * \\
(0.012)\end{array}$ & $\begin{array}{c}-0.22 * * * \\
(0.012)\end{array}$ & $\begin{array}{c}-0.21 * * * \\
(0.013)\end{array}$ & $\begin{array}{c}-0.17 * * * \\
(0.014)\end{array}$ & $\begin{array}{c}-0.15 * * * \\
(0.015)\end{array}$ \\
\hline age & $\begin{array}{c}0.04 * * * \\
(0.007)\end{array}$ & $\begin{array}{c}0.03^{* * *} \\
(0.006)\end{array}$ & $\begin{array}{c}0.03^{* * *} \\
(0.006)\end{array}$ & $\begin{array}{c}0.03^{* * *} \\
(0.006)\end{array}$ & $\begin{array}{c}0.03^{* * *} \\
(0.006)\end{array}$ & $\begin{array}{c}0.03 * * * \\
(0.006)\end{array}$ \\
\hline agesq & $\begin{array}{c}-0.00 * * * \\
(0.000)\end{array}$ & $\begin{array}{c}-0.00 * * * \\
(0.000)\end{array}$ & $\begin{array}{c}-0.00 * * * \\
(0.000)\end{array}$ & $\begin{array}{c}-0.00 * * * \\
(0.000)\end{array}$ & $\begin{array}{c}-0.00 * * * \\
(0.000)\end{array}$ & $\begin{array}{c}-0.00 * * * \\
(0.000)\end{array}$ \\
\hline male & $\begin{array}{c}0.10^{* * *} \\
(0.013)\end{array}$ & $\begin{array}{c}0.10^{* * *} \\
(0.013)\end{array}$ & $\begin{array}{c}0.10 * * * \\
(0.014)\end{array}$ & $\begin{array}{c}0.08^{* * *} \\
(0.013)\end{array}$ & $\begin{array}{c}0.08^{* * *} \\
(0.013)\end{array}$ & $\begin{array}{c}0.07 * * * \\
(0.013)\end{array}$ \\
\hline preveduc & $\begin{array}{c}0.03^{*} \\
(0.013)\end{array}$ & $\begin{array}{c}-0.02 \\
(0.010)\end{array}$ & $\begin{array}{c}-0.02 \\
(0.010)\end{array}$ & $\begin{array}{c}-0.01 \\
(0.011)\end{array}$ & $\begin{array}{c}-0.01 \\
(0.011)\end{array}$ & $\begin{array}{c}-0.00 \\
(0.013)\end{array}$ \\
\hline prevunemp & $\begin{array}{c}-0.14 * * * \\
(0.025)\end{array}$ & $\begin{array}{c}-0.13 * * * \\
(0.022)\end{array}$ & $\begin{array}{c}-0.13 * * * \\
(0.022)\end{array}$ & $\begin{array}{c}-0.11^{* * *} \\
(0.020)\end{array}$ & $\begin{array}{c}-0.11^{* * *} \\
(0.020)\end{array}$ & $\begin{array}{c}-0.08 * * * \\
(0.020)\end{array}$ \\
\hline prevoth & $\begin{array}{l}-0.05^{*} \\
(0.025)\end{array}$ & $\begin{array}{c}-0.06^{* *} \\
(0.025)\end{array}$ & $\begin{array}{c}-0.06^{* *} \\
(0.025)\end{array}$ & $\begin{array}{c}-0.04 \\
(0.026)\end{array}$ & $\begin{array}{c}-0.04 \\
(0.025)\end{array}$ & $\begin{array}{c}-0.03 \\
(0.027)\end{array}$ \\
\hline teacher & $\begin{array}{c}0.02 \\
(0.029)\end{array}$ & $\begin{array}{c}0.01 \\
(0.029)\end{array}$ & $\begin{array}{c}0.01 \\
(0.029)\end{array}$ & $\begin{array}{c}0.04 \\
(0.027)\end{array}$ & $\begin{array}{c}0.04 \\
(0.027)\end{array}$ & $\begin{array}{c}0.04 * \\
(0.023)\end{array}$ \\
\hline humanities & $\begin{array}{c}-0.02 \\
(0.013)\end{array}$ & $\begin{array}{c}-0.01 \\
(0.013)\end{array}$ & $\begin{array}{c}-0.01 \\
(0.014)\end{array}$ & $\begin{array}{c}-0.02 \\
(0.012)\end{array}$ & $\begin{array}{l}-0.02 * \\
(0.013)\end{array}$ & $\begin{array}{l}-0.03 * * \\
(0.013)\end{array}$ \\
\hline econ & $\begin{array}{c}0.07 * * * \\
(0.014)\end{array}$ & $\begin{array}{c}0.07 * * * \\
(0.014)\end{array}$ & $\begin{array}{c}0.07 * * * \\
(0.014)\end{array}$ & $\begin{array}{c}0.06^{* * *} \\
(0.012)\end{array}$ & $\begin{array}{c}0.05^{* * *} \\
(0.011)\end{array}$ & $\begin{array}{c}0.05^{* * *} \\
(0.014)\end{array}$ \\
\hline othersocial & $\begin{array}{c}-0.02 \\
(0.012)\end{array}$ & $\begin{array}{c}-0.02 \\
(0.013)\end{array}$ & $\begin{array}{c}-0.02 \\
(0.013)\end{array}$ & $\begin{array}{l}-0.02^{*} \\
(0.012)\end{array}$ & $\begin{array}{c}-0.03^{* *} \\
(0.012)\end{array}$ & $\begin{array}{c}-0.02^{* *} \\
(0.011)\end{array}$ \\
\hline natural & $\begin{array}{c}0.01 \\
(0.016)\end{array}$ & $\begin{array}{c}0.01 \\
(0.017)\end{array}$ & $\begin{array}{c}0.01 \\
(0.017)\end{array}$ & $\begin{array}{c}0.00 \\
(0.016)\end{array}$ & $\begin{array}{c}-0.00 \\
(0.016)\end{array}$ & $\begin{array}{c}-0.02 \\
(0.016)\end{array}$ \\
\hline maths & $\begin{array}{c}0.04 \\
(0.027)\end{array}$ & $\begin{array}{c}0.04 \\
(0.026)\end{array}$ & $\begin{array}{c}0.04 \\
(0.026)\end{array}$ & $\begin{array}{c}0.03 \\
(0.024)\end{array}$ & $\begin{array}{c}0.03 \\
(0.024)\end{array}$ & $\begin{array}{c}0.03 \\
(0.019)\end{array}$ \\
\hline ict & $\begin{array}{c}0.07 * * * \\
(0.017)\end{array}$ & $\begin{array}{c}0.07 * * * \\
(0.017)\end{array}$ & $\begin{array}{c}0.07 * * * \\
(0.018)\end{array}$ & $\begin{array}{c}0.05^{* * *} \\
(0.016)\end{array}$ & $\begin{array}{l}0.04 * * \\
(0.016)\end{array}$ & $\begin{array}{l}0.04 * * \\
(0.014)\end{array}$ \\
\hline engineering & $\begin{array}{c}0.07 * * * \\
(0.017)\end{array}$ & $\begin{array}{c}0.08^{* * *} \\
(0.018)\end{array}$ & $\begin{array}{c}0.08 * * * \\
(0.018)\end{array}$ & $\begin{array}{c}0.06^{* * *} \\
(0.017)\end{array}$ & $\begin{array}{l}0.05^{* *} \\
(0.017)\end{array}$ & $\begin{array}{l}0.04 * * \\
(0.016)\end{array}$ \\
\hline agri & $\begin{array}{c}-0.05 \\
(0.037)\end{array}$ & $\begin{array}{c}-0.05 \\
(0.038)\end{array}$ & $\begin{array}{c}-0.05 \\
(0.038)\end{array}$ & $\begin{array}{c}-0.05 \\
(0.040)\end{array}$ & $\begin{array}{c}-0.05 \\
(0.038)\end{array}$ & $\begin{array}{l}-0.06^{*} \\
(0.034)\end{array}$ \\
\hline medicine & $\begin{array}{c}0.02 \\
(0.018)\end{array}$ & $\begin{array}{c}0.01 \\
(0.020)\end{array}$ & $\begin{array}{c}0.01 \\
(0.020)\end{array}$ & $\begin{array}{c}0.01 \\
(0.018)\end{array}$ & $\begin{array}{c}0.02 \\
(0.018)\end{array}$ & $\begin{array}{c}0.03 \\
(0.019)\end{array}$ \\
\hline service & $\begin{array}{c}-0.05 * * * \\
(0.015)\end{array}$ & $\begin{array}{c}-0.06 * * * \\
(0.016)\end{array}$ & $\begin{array}{c}-0.07 * * * \\
(0.016)\end{array}$ & $\begin{array}{c}-0.07 * * * \\
(0.015)\end{array}$ & $\begin{array}{c}-0.06 * * * \\
(0.015)\end{array}$ & $\begin{array}{c}-0.07 * * * \\
(0.017)\end{array}$ \\
\hline emptenure & & $\begin{array}{c}0.01^{* * *} \\
(0.003)\end{array}$ & $\begin{array}{c}0.01^{* * *} \\
(0.003)\end{array}$ & $\begin{array}{l}0.01^{* *} \\
(0.003)\end{array}$ & $\begin{array}{l}0.01^{* *} \\
(0.003)\end{array}$ & $\begin{array}{l}0.01^{* *} \\
(0.003)\end{array}$ \\
\hline emptenuresq & & $\begin{array}{c}-0.00^{* *} \\
(0.000)\end{array}$ & $\begin{array}{c}-0.00^{* *} \\
(0.000)\end{array}$ & $\begin{array}{c}-0.00 \\
(0.000)\end{array}$ & $\begin{array}{c}-0.00 \\
(0.000)\end{array}$ & $\begin{array}{c}-0.00 \\
(0.000)\end{array}$ \\
\hline train_courses_in & & $\begin{array}{c}0.05^{* * *} \\
(0.012)\end{array}$ & $\begin{array}{c}0.04 * * * \\
(0.012)\end{array}$ & $\begin{array}{c}0.03^{* *} \\
(0.012)\end{array}$ & $\begin{array}{c}0.02 * \\
(0.012)\end{array}$ & $\begin{array}{c}0.02 \\
(0.013)\end{array}$ \\
\hline train_courses_out & & $\begin{array}{c}0.02 * \\
(0.013)\end{array}$ & $\begin{array}{c}0.02 * \\
(0.013)\end{array}$ & $\begin{array}{c}0.02 * \\
(0.012)\end{array}$ & $\begin{array}{c}0.02 \\
(0.012)\end{array}$ & $\begin{array}{c}0.01 \\
(0.012)\end{array}$ \\
\hline train_ojt & & $\begin{array}{c}0.00 \\
(0.010)\end{array}$ & $\begin{array}{c}0.00 \\
(0.010)\end{array}$ & $\begin{array}{l}-0.00 \\
(0.009)\end{array}$ & $\begin{array}{c}-0.01 \\
(0.008)\end{array}$ & $\begin{array}{c}-0.00 \\
(0.009)\end{array}$ \\
\hline
\end{tabular}




\begin{tabular}{|c|c|c|c|c|}
\hline overskilled & $\begin{array}{l}-0.02 * \\
(0.009)\end{array}$ & $\begin{array}{l}-0.02 * * \\
(0.009)\end{array}$ & $\begin{array}{l}-0.02 * \\
(0.008)\end{array}$ & $\begin{array}{c}-0.00 \\
(0.007)\end{array}$ \\
\hline skilldef & $\begin{array}{c}-0.00 \\
(0.001)\end{array}$ & $\begin{array}{c}-0.00 \\
(0.001)\end{array}$ & $\begin{array}{c}-0.00 \\
(0.001)\end{array}$ & $\begin{array}{c}-0.00 \\
(0.001)\end{array}$ \\
\hline temporary & & $\begin{array}{c}-0.04 * * * \\
(0.016)\end{array}$ & $\begin{array}{c}-0.04 * * * \\
(0.016)\end{array}$ & $\begin{array}{l}-0.04^{* *} \\
(0.018)\end{array}$ \\
\hline informal & & $\begin{array}{c}-0.05^{* *} \\
(0.021)\end{array}$ & $\begin{array}{l}-0.05^{* *} \\
(0.022)\end{array}$ & $\begin{array}{l}-0.05^{*} \\
(0.026)\end{array}$ \\
\hline multisite & & $\begin{array}{c}0.03^{* * *} \\
(0.008)\end{array}$ & $\begin{array}{c}0.03^{* * *} \\
(0.008)\end{array}$ & $\begin{array}{c}0.03 * * * \\
(0.007)\end{array}$ \\
\hline private & & $\begin{array}{c}0.02 \\
(0.015)\end{array}$ & $\begin{array}{c}0.02 \\
(0.015)\end{array}$ & $\begin{array}{c}0.02 \\
(0.013)\end{array}$ \\
\hline size10to49 & & $\begin{array}{c}0.07 * * * \\
(0.017)\end{array}$ & $\begin{array}{c}0.07 * * * \\
(0.017)\end{array}$ & $\begin{array}{c}0.07 * * * \\
(0.017)\end{array}$ \\
\hline size50to99 & & $\begin{array}{c}0.08 * * * \\
(0.019)\end{array}$ & $\begin{array}{c}0.08^{* * *} \\
(0.019)\end{array}$ & $\begin{array}{c}0.07 * * * \\
(0.018)\end{array}$ \\
\hline size100to249 & & $\begin{array}{c}0.15^{* * *} \\
(0.019)\end{array}$ & $\begin{array}{c}0.14^{* * *} \\
(0.019)\end{array}$ & $\begin{array}{c}0.13^{* * *} \\
(0.020)\end{array}$ \\
\hline size250to499 & & $\begin{array}{c}0.16^{* * *} \\
(0.015)\end{array}$ & $\begin{array}{c}0.15^{* * *} \\
(0.015)\end{array}$ & $\begin{array}{c}0.15 * * * \\
(0.017)\end{array}$ \\
\hline size500 & & $\begin{array}{c}0.18 * * * \\
(0.022)\end{array}$ & $\begin{array}{c}0.18^{* * *} \\
(0.022)\end{array}$ & $\begin{array}{c}0.16 * * * \\
(0.022)\end{array}$ \\
\hline jobnrout & & $\begin{array}{c}-0.01 \\
(0.016)\end{array}$ & $\begin{array}{c}-0.01 \\
(0.015)\end{array}$ & $\begin{array}{c}-0.01 \\
(0.014)\end{array}$ \\
\hline joblearn & & $\begin{array}{l}-0.03 * * \\
(0.010)\end{array}$ & $\begin{array}{c}-0.03 * * * \\
(0.010)\end{array}$ & $\begin{array}{c}-0.04 * * * \\
(0.012)\end{array}$ \\
\hline jobaut & & $\begin{array}{c}0.04 * * * \\
(0.008)\end{array}$ & $\begin{array}{c}0.04^{* * *} \\
(0.008)\end{array}$ & $\begin{array}{l}0.02^{* *} \\
(0.009)\end{array}$ \\
\hline jobteam & & $\begin{array}{c}-0.03 * * * \\
(0.007)\end{array}$ & $\begin{array}{c}-0.03 * * * \\
(0.007)\end{array}$ & $\begin{array}{c}-0.03 * * * \\
(0.007)\end{array}$ \\
\hline role_promoted & & $\begin{array}{c}0.07 * * * \\
(0.014)\end{array}$ & $\begin{array}{c}0.07 * * * \\
(0.014)\end{array}$ & $\begin{array}{c}0.07 * * * \\
(0.014)\end{array}$ \\
\hline advlit & & & $\begin{array}{c}0.07 * * * \\
(0.012)\end{array}$ & $\begin{array}{c}0.07 * * * \\
(0.010)\end{array}$ \\
\hline advnum & & & $\begin{array}{c}0.02 \\
(0.010)\end{array}$ & $\begin{array}{c}0.01 \\
(0.011)\end{array}$ \\
\hline modict & & & $\begin{array}{c}0.04^{* *} \\
(0.015)\end{array}$ & $\begin{array}{c}0.03 \\
(0.016)\end{array}$ \\
\hline advict & & & $\begin{array}{l}0.05 * * \\
(0.019)\end{array}$ & $\begin{array}{c}0.03 \\
(0.021)\end{array}$ \\
\hline highiskill & & & $\begin{array}{c}0.03^{* * *} \\
(0.008)\end{array}$ & $\begin{array}{c}0.02 * \\
(0.008)\end{array}$ \\
\hline factor_suitskills & & & & $\begin{array}{c}0.01 * * * \\
(0.003)\end{array}$ \\
\hline factor_experience & & & & $\begin{array}{c}-0.01 * * * \\
(0.003)\end{array}$ \\
\hline factor_security & & & & $\begin{array}{c}-0.01 * * * \\
(0.003)\end{array}$ \\
\hline factor_career & & & & $\begin{array}{c}0.01 \\
(0.003)\end{array}$ \\
\hline
\end{tabular}


factor_reputation

factor_benefits

$0.02 * * *$

factor_closehome

(0.002)

$-0.01 * * *$

factor_intrinsic

$(0.002)$

tactor intrinsic

$0.01 *$

factor_worklife

Country dummies
Constant

Constant

$\begin{array}{ccc}\text { YES } & \text { YES } & \text { YES } \\ 1.75^{* * *} & 1.92^{* * *} & 1.94^{* * *} \\ (0.158) & (0.139) & (0.147)\end{array}$

YES

(0.002)

Observations

16,880

16,845

16,811

(0.138)

YES

YES

R-squared

0.58

0.59

0.58

16,811

(0.138)

$1.74 * * *$

(0.145)

NB: Robust standard errors in parentheses, clustered for country; ${ }^{* * *} \mathrm{p}<0.01,{ }^{* *} \mathrm{p}<0.05,{ }^{*} \mathrm{p}<0.1$

16,811

14,868

Source: Cedefop European skills and job (ESJ) survey 
Table 4: OLS estimates of wage equation, medium educated adult employees, 2014, EU28

\begin{tabular}{|c|c|c|c|c|c|c|}
\hline & $\begin{array}{c}(1) \\
\text { Basic HC }\end{array}$ & $\begin{array}{c}(2) \\
\text { Augmented } \\
H C\end{array}$ & $\begin{array}{c}(3) \\
\text { Skill } \\
\text { mismatch }\end{array}$ & $\begin{array}{l}(4) \\
\text { Job }\end{array}$ & $\begin{array}{c}\text { (5) } \\
\text { Skill needs }\end{array}$ & $\begin{array}{c}\text { (6) } \\
\text { Motives }\end{array}$ \\
\hline overeducated & $\begin{array}{c}-0.18 * * * \\
(0.022)\end{array}$ & $\begin{array}{c}-0.15 * * * \\
(0.020)\end{array}$ & $\begin{array}{c}-0.15 * * * \\
(0.020)\end{array}$ & $\begin{array}{c}-0.14 * * * \\
(0.020)\end{array}$ & $\begin{array}{c}-\mathbf{- 0 . 0 9} * * * \\
(0.020)\end{array}$ & $\begin{array}{c}-0.08 * * * \\
(0.018)\end{array}$ \\
\hline age & $\begin{array}{c}0.02 * * * \\
(0.007)\end{array}$ & $\begin{array}{c}0.01 \\
(0.007)\end{array}$ & $\begin{array}{c}0.01 \\
(0.007)\end{array}$ & $\begin{array}{c}0.01 \\
(0.007)\end{array}$ & $\begin{array}{c}0.01 \\
(0.007)\end{array}$ & $\begin{array}{l}0.01 * * \\
(0.006)\end{array}$ \\
\hline agesq & $\begin{array}{l}-0.00^{*} \\
(0.000)\end{array}$ & $\begin{array}{c}-0.00 \\
(0.000)\end{array}$ & $\begin{array}{c}-0.00 \\
(0.000)\end{array}$ & $\begin{array}{c}-0.00 \\
(0.000)\end{array}$ & $\begin{array}{c}-0.00 \\
(0.000)\end{array}$ & $\begin{array}{l}-0.00^{*} \\
(0.000)\end{array}$ \\
\hline male & $\begin{array}{c}0.13^{* * *} \\
(0.018)\end{array}$ & $\begin{array}{c}0.12 * * * \\
(0.018)\end{array}$ & $\begin{array}{c}0.13^{* * *} \\
(0.019)\end{array}$ & $\begin{array}{c}0.11 * * * \\
(0.018)\end{array}$ & $\begin{array}{c}0.11^{* * *} \\
(0.018)\end{array}$ & $\begin{array}{c}0.10 * * * \\
(0.018)\end{array}$ \\
\hline preveduc & $\begin{array}{l}0.05^{* *} \\
(0.020)\end{array}$ & $\begin{array}{l}-0.04^{* *} \\
(0.016)\end{array}$ & $\begin{array}{c}-0.04 * * \\
(0.016)\end{array}$ & $\begin{array}{c}-0.03^{* *} \\
(0.016)\end{array}$ & $\begin{array}{c}-0.03^{* *} \\
(0.016)\end{array}$ & $\begin{array}{l}-0.03^{* *} \\
(0.017)\end{array}$ \\
\hline prevunemp & $\begin{array}{c}-0.14 * * * \\
(0.027)\end{array}$ & $\begin{array}{c}-0.12 * * * \\
(0.023)\end{array}$ & $\begin{array}{c}-0.12 * * * \\
(0.023)\end{array}$ & $\begin{array}{c}-0.11 * * * \\
(0.022)\end{array}$ & $\begin{array}{c}-0.11 * * * \\
(0.023)\end{array}$ & $\begin{array}{c}-0.11 * * * \\
(0.024)\end{array}$ \\
\hline prevoth & $\begin{array}{c}-0.06 * * \\
(0.027)\end{array}$ & $\begin{array}{c}-0.07 * * \\
(0.028)\end{array}$ & $\begin{array}{l}-0.07 * * \\
(0.028)\end{array}$ & $\begin{array}{l}-0.06 * * \\
(0.028)\end{array}$ & $\begin{array}{l}-0.05^{*} \\
(0.029)\end{array}$ & $\begin{array}{l}-0.06^{*} \\
(0.033)\end{array}$ \\
\hline emptenure & & $\begin{array}{c}0.01 * * * \\
(0.002)\end{array}$ & $\begin{array}{c}0.01 * * * \\
(0.002)\end{array}$ & $\begin{array}{c}0.01 * * * \\
(0.002)\end{array}$ & $\begin{array}{c}0.01 * * * \\
(0.002)\end{array}$ & $\begin{array}{c}0.01 * * * \\
(0.002)\end{array}$ \\
\hline emptenuresq & & $\begin{array}{c}-0.00 * * * \\
(0.000)\end{array}$ & $\begin{array}{c}-0.00 * * * \\
(0.000)\end{array}$ & $\begin{array}{c}-0.00^{* *} \\
(0.000)\end{array}$ & $\begin{array}{c}-0.00^{* *} \\
(0.000)\end{array}$ & $\begin{array}{l}-0.00^{*} \\
(0.000)\end{array}$ \\
\hline train_courses_in & & $\begin{array}{c}0.08 * * * \\
(0.012)\end{array}$ & $\begin{array}{c}0.08 * * * \\
(0.012)\end{array}$ & $\begin{array}{c}0.06^{* * *} \\
(0.012)\end{array}$ & $\begin{array}{c}0.05^{* * *} \\
(0.012)\end{array}$ & $\begin{array}{c}0.04 * * * \\
(0.011)\end{array}$ \\
\hline train_courses_out & & $\begin{array}{l}0.03 * * \\
(0.014)\end{array}$ & $\begin{array}{l}0.03 * * \\
(0.014)\end{array}$ & $\begin{array}{c}0.03^{* *} \\
(0.014)\end{array}$ & $\begin{array}{c}0.02 \\
(0.015)\end{array}$ & $\begin{array}{c}0.02 \\
(0.015)\end{array}$ \\
\hline train_ojt & & $\begin{array}{c}0.04^{* * *} \\
(0.010)\end{array}$ & $\begin{array}{c}0.04 * * * \\
(0.010)\end{array}$ & $\begin{array}{l}0.03 * * \\
(0.010)\end{array}$ & $\begin{array}{l}0.02 * * \\
(0.010)\end{array}$ & $\begin{array}{c}0.03 * * \\
(0.010)\end{array}$ \\
\hline overskilled & & & $\begin{array}{c}-0.01 \\
(0.010)\end{array}$ & $\begin{array}{c}-0.02 \\
(0.009)\end{array}$ & $\begin{array}{c}-0.01 \\
(0.009)\end{array}$ & $\begin{array}{c}-0.01 \\
(0.010)\end{array}$ \\
\hline skilldef & & & $\begin{array}{c}-0.00 \\
(0.000)\end{array}$ & $\begin{array}{c}0.00 \\
(0.000)\end{array}$ & $\begin{array}{c}0.00 \\
(0.000)\end{array}$ & $\begin{array}{c}0.00 \\
(0.000)\end{array}$ \\
\hline temporary & & & & $\begin{array}{c}-0.08 * * * \\
(0.019)\end{array}$ & $\begin{array}{c}-0.07 * * * \\
(0.018)\end{array}$ & $\begin{array}{c}-0.08 * * * \\
(0.021)\end{array}$ \\
\hline informal & & & & $\begin{array}{c}-0.02 \\
(0.049)\end{array}$ & $\begin{array}{c}-0.01 \\
(0.049)\end{array}$ & $\begin{array}{c}0.03 \\
(0.055)\end{array}$ \\
\hline multisite & & & & $\begin{array}{c}0.02 \\
(0.011)\end{array}$ & $\begin{array}{c}0.01 \\
(0.011)\end{array}$ & $\begin{array}{c}0.01 \\
(0.012)\end{array}$ \\
\hline private & & & & $\begin{array}{c}0.03^{*} \\
(0.015)\end{array}$ & $\begin{array}{c}0.03^{*} \\
(0.015)\end{array}$ & $\begin{array}{c}0.02 \\
(0.017)\end{array}$ \\
\hline size10to49 & & & & $\begin{array}{l}0.04^{* *} \\
(0.016)\end{array}$ & $\begin{array}{l}0.04^{* *} \\
(0.016)\end{array}$ & $\begin{array}{c}0.03^{*} \\
(0.017)\end{array}$ \\
\hline size50to99 & & & & $\begin{array}{l}0.04^{* *} \\
(0.018)\end{array}$ & $\begin{array}{l}0.04^{* *} \\
(0.017)\end{array}$ & $\begin{array}{l}0.03^{* *} \\
(0.016)\end{array}$ \\
\hline size100to249 & & & & $\begin{array}{c}0.08 * * * \\
(0.023)\end{array}$ & $\begin{array}{c}0.07 * * * \\
(0.023)\end{array}$ & $\begin{array}{c}0.07 * * * \\
(0.023)\end{array}$ \\
\hline size250to499 & & & & $\begin{array}{c}0.12 * * * \\
(0.025)\end{array}$ & $\begin{array}{c}0.12 * * * \\
(0.025)\end{array}$ & $\begin{array}{c}0.11 * * * \\
(0.025)\end{array}$ \\
\hline size 500 & & & & $\begin{array}{c}0.15^{* * *} \\
(0.020)\end{array}$ & $\begin{array}{c}0.14^{* * * *} \\
(0.019)\end{array}$ & $\begin{array}{c}0.13 * * * \\
(0.016)\end{array}$ \\
\hline
\end{tabular}




\begin{tabular}{|c|c|c|c|c|c|c|}
\hline jobnrout & & & & $\begin{array}{l}-0.00 \\
(0.014)\end{array}$ & $\begin{array}{c}-0.01 \\
(0.014)\end{array}$ & $\begin{array}{c}-0.01 \\
(0.015)\end{array}$ \\
\hline joblearn & & & & -0.00 & -0.01 & -0.01 \\
\hline & & & & $(0.013)$ & $(0.013)$ & $(0.015)$ \\
\hline jobaut & & & & $0.03 * *$ & $0.02 *$ & 0.01 \\
\hline & & & & $(0.011)$ & $(0.012)$ & $(0.012)$ \\
\hline jobteam & & & & 0.00 & 0.01 & 0.00 \\
\hline & & & & $(0.015)$ & $(0.016)$ & $(0.016)$ \\
\hline role_promoted & & & & $0.09 * * *$ & $0.07 * * *$ & $0.07 * * *$ \\
\hline & & & & $(0.022)$ & $(0.022)$ & $(0.022)$ \\
\hline advlit & & & & & $0.05 * * *$ & $0.06 * * *$ \\
\hline & & & & & $(0.012)$ & $(0.013)$ \\
\hline advnum & & & & & 0.00 & -0.00 \\
\hline & & & & & $(0.012)$ & $(0.012)$ \\
\hline modict & & & & & $0.09 * * *$ & $0.08 * * *$ \\
\hline & & & & & $(0.011)$ & $(0.010)$ \\
\hline advict & & & & & $0.12 * * *$ & $0.11 * * *$ \\
\hline & & & & & $(0.023)$ & $(0.025)$ \\
\hline highiskill & & & & & 0.01 & 0.01 \\
\hline & & & & & $(0.012)$ & $(0.012)$ \\
\hline factor_suitskills & & & & & & 0.00 \\
\hline & & & & & & $(0.002)$ \\
\hline factor_experience & & & & & & $-0.01 * * *$ \\
\hline & & & & & & $(0.002)$ \\
\hline factor_security & & & & & & $-0.01^{*}$ \\
\hline & & & & & & $(0.003)$ \\
\hline factor_career & & & & & & $0.01 * *$ \\
\hline & & & & & & $(0.003)$ \\
\hline factor_reputation & & & & & & -0.00 \\
\hline & & & & & & $(0.002)$ \\
\hline factor_benefits & & & & & & $0.02 * * *$ \\
\hline & & & & & & $(0.003)$ \\
\hline factor_closehome & & & & & & $-0.01 * * *$ \\
\hline & & & & & & $(0.001)$ \\
\hline factor_intrinsic & & & & & & 0.00 \\
\hline & & & & & & $(0.002)$ \\
\hline factor_worklife & & & & & & $0.01 * * *$ \\
\hline & & & & & & $(0.003)$ \\
\hline Country dummies & YES & YES & YES & YES & YES & YES \\
\hline Constant & $2.06 * * *$ & $2.20 * * *$ & $2.20 * * *$ & $2.11 * * *$ & $2.00 * * *$ & $1.98 * * *$ \\
\hline & $(0.137)$ & $(0.139)$ & $(0.138)$ & $(0.140)$ & $(0.139)$ & $(0.133)$ \\
\hline Observations & 14,500 & 14,451 & 14,403 & 14,403 & 14,403 & 12,802 \\
\hline R-squared & 0.59 & 0.60 & 0.60 & 0.60 & 0.61 & 0.61 \\
\hline
\end{tabular}

NB: Robust standard errors in parentheses, clustered for country; ${ }^{* * *} \mathrm{p}<0.01,{ }^{* *} \mathrm{p}<0.05,{ }^{*} \mathrm{p}<0.1$

Source: Cedefop European skills and job (ESJ) survey 
Table 5: Decomposition analysis of wage differences between matched and overeducated employees, adult employees, 2014, EU28

\begin{tabular}{|l|c|c|c|}
\hline & $\begin{array}{c}\text { All sample } \\
\text { excl. Low- } \\
\text { educated }\end{array}$ & $\begin{array}{c}\text { Medium- } \\
\text { educated }\end{array}$ & $\begin{array}{c}\text { High- } \\
\text { educated }\end{array}$ \\
\hline Amount attributable: & 0.8 & -21.1 & 15.2 \\
\hline - due to endowments (E): & 4.9 & 3.6 & 12.0 \\
\hline - due to coefficients (C): & -4.1 & -24.7 & 3.1 \\
\hline Shift coefficient (U): & 16.7 & 32.7 & 12.5 \\
\hline Raw differential (R) $\{\mathrm{E}+\mathrm{C}+\mathrm{U}\}:$ & 17.4 & 11.5 & 27.7 \\
\hline Adjusted differential (D) $\{\mathrm{C}+\mathrm{U}\}:$ & 12.5 & 7.9 & 15.7 \\
\hline & & & \\
\hline Endowments as \% total (E/R): & 28.1 & 31.1 & 43.4 \\
\hline Discrimination as \% total (D/R): & 71.9 & 68.9 & 56.6 \\
\hline
\end{tabular}

Source: Cedefop European Skills and Jobs (ESJ) survey

Table 6: Contribution of endowments in wage differences between matched and overeducated employees, adult employees, 2014, EU28

\begin{tabular}{|c|c|c|c|}
\hline & All & High & Medium \\
\hline \multicolumn{4}{|l|}{ \% of total raw difference } \\
\hline $\mathrm{HC}$ & $5 \%$ & $16 \%$ & $27 \%$ \\
\hline Job & $9 \%$ & $7 \%$ & $15 \%$ \\
\hline Skill needs & $18 \%$ & $7 \%$ & $36 \%$ \\
\hline Motives & $11 \%$ & $9 \%$ & $15 \%$ \\
\hline Country FE & $-15 \%$ & $4 \%$ & $-60 \%$ \\
\hline Total endowment & $28 \%$ & $43 \%$ & $31 \%$ \\
\hline \multicolumn{4}{|l|}{$\%$ total endowment } \\
\hline - Quadratic age & $20 \%$ & $13 \%$ & $8 \%$ \\
\hline - Quadratic employer tenure & $29 \%$ & $4 \%$ & $47 \%$ \\
\hline - High education & $-55 \%$ & & \\
\hline - Past unemployment & $10 \%$ & $4 \%$ & $14 \%$ \\
\hline - Training in work & $4 \%$ & $2 \%$ & $8 \%$ \\
\hline - Field of study: Education & . & $3 \%$ & 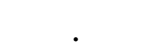 \\
\hline - Field of study: Humanities & . & $2 \%$ & . \\
\hline - Field of study: Economics & . & $-2 \%$ & . \\
\hline - Field of study: Engineering & . & $2 \%$ & \\
\hline - Overskilled & $4 \%$ & $3 \%$ & $6 \%$ \\
\hline \multicolumn{4}{|l|}{ Job } \\
\hline - Temporary contract & $4 \%$ & $1 \%$ & $11 \%$ \\
\hline - Size of workplace: 1-9 & $10 \%$ & $8 \%$ & $8 \%$ \\
\hline - Promoted & $16 \%$ & $7 \%$ & $25 \%$ \\
\hline - Private & $-4 \%$ & $-2 \%$ & $-3 \%$ \\
\hline - Learning in job & $-4 \%$ & $-3 \%$ & $0 \%$ \\
\hline \multicolumn{4}{|l|}{ Skill needs } \\
\hline - Advanced literacy & $27 \%$ & $14 \%$ & $33 \%$ \\
\hline - Advanced numeracy & $8 \%$ & $3 \%$ & $0 \%$ \\
\hline - Moderate ICT & $8 \%$ & $-1 \%$ & $44 \%$ \\
\hline - Advanced ICT & $14 \%$ & $-3 \%$ & $31 \%$ \\
\hline - High level of soft skills & $6 \%$ & $3 \%$ & $6 \%$ \\
\hline
\end{tabular}




\begin{tabular}{lccc}
\hline Motives & & & \\
Information & & & \\
- Suits qualifications \& skills & $24 \%$ & $18 \%$ & $14 \%$ \\
- Pay \& benefits & $22 \%$ & $8 \%$ & $33 \%$ \\
Career concerns & & $-5 \%$ & $-22 \%$ \\
- Gain work experience & $-14 \%$ & $2 \%$ & $28 \%$ \\
- Career prospects & $12 \%$ & $-3 \%$ & $-3 \%$ \\
Job attributes & & $2 \%$ & $0 \%$ \\
- Employer reputation & $-4 \%$ & $1 \%$ & $-8 \%$ \\
- Close to home & $2 \%$ & $1 \%$ & $14 \%$ \\
- Intrinsic satisfaction & & $-3 \%$ & $-8 \%$ \\
- Work-life balance & & & \\
- Job security & &
\end{tabular}

Source: Cedefop European Skills and Jobs (ESJ) survey

Table 7: Unexplained raw wage differences between matched and overeducated employees, adult employees, 2014, EU28

\begin{tabular}{|c|c|c|c|}
\hline & All & High & Medium \\
\hline \multicolumn{4}{|l|}{ \% total raw difference } \\
\hline $\mathrm{HC}$ & $71 \%$ & $96 \%$ & $-163 \%$ \\
\hline Job & $9 \%$ & $12 \%$ & $-7 \%$ \\
\hline Skill needs & $-22 \%$ & $-32 \%$ & $-10 \%$ \\
\hline Motives & $-47 \%$ & $-51 \%$ & $10 \%$ \\
\hline Country FE & $-33 \%$ & $-12 \%$ & $-46 \%$ \\
\hline \multicolumn{4}{|l|}{ HC } \\
\hline - Age & $82 \%$ & $194 \%$ & $-325 \%$ \\
\hline - Age square & $-10 \%$ & $-63 \%$ & $200 \%$ \\
\hline - Male & $-5 \%$ & $0 \%$ & $-24 \%$ \\
\hline $\begin{array}{l}\text { - High education } \\
\text { - Previously in education \& }\end{array}$ & $39 \%$ & . & . \\
\hline training & $1 \%$ & $3 \%$ & $-7 \%$ \\
\hline - Previously in unemployment & $-1 \%$ & $-1 \%$ & $4 \%$ \\
\hline - Overskilled & $-6 \%$ & $-10 \%$ & $19 \%$ \\
\hline - Skill deficit & $5 \%$ & $-1 \%$ & $20 \%$ \\
\hline - Employer tenure & $-43 \%$ & $-44 \%$ & $-30 \%$ \\
\hline - Employer tenure square & $14 \%$ & $12 \%$ & $15 \%$ \\
\hline - Training courses during work & $2 \%$ & $5 \%$ & $-17 \%$ \\
\hline - Training courses out of work & $-1 \%$ & $1 \%$ & $-8 \%$ \\
\hline - Training as part of work & $-4 \%$ & $-1 \%$ & $-11 \%$ \\
\hline \multicolumn{4}{|l|}{ Job } \\
\hline - Temporary contract & $-1 \%$ & $1 \%$ & $-9 \%$ \\
\hline - Informal contract & $-2 \%$ & $-1 \%$ & $-5 \%$ \\
\hline - Multi site workplace & $12 \%$ & $14 \%$ & $4 \%$ \\
\hline - Private sector & $-6 \%$ & $-8 \%$ & $16 \%$ \\
\hline - Size1to9 & $-3 \%$ & $-1 \%$ & $-11 \%$ \\
\hline - Size10to49 & $-1 \%$ & $-2 \%$ & $3 \%$ \\
\hline - Size50to99 & $0 \%$ & $1 \%$ & $-3 \%$ \\
\hline - Size100to249 & $2 \%$ & $1 \%$ & $4 \%$ \\
\hline
\end{tabular}


- Size250to499

- Size500

- Non-routine job

- Job with need to learn

- Job with autonomy

- Job in teams

- Promotion

Skill needs

- Advanced literacy

- Advanced numeracy

- Moderate ICT

- Advanced ICT

- High level of soft skills

\section{Motives}

\section{Information}

- Suits qualifications \& skills

- Pay and benefits

Career concerns

- Gain work experience

- Career progression

Job attributes

- Job security

- Employer reputation

- Close to home

- Intrinsic reasons

- Work-life balance
$-1 \%$

$2 \%$

$3 \%$

$3 \%$

2\%

$-3 \%$

$1 \%$

$-7 \%$

$5 \%$

$-17 \%$

$-6 \%$

$3 \%$

$29 \%$

$14 \%$

24\%

$19 \%$

$46 \%$

$-3 \%$

$17 \%$

$12 \%$

$17 \%$

$-17 \%$

$-26 \%$

$17 \%$

$-26 \%$

$-32 \%$

$-5 \%$

$13 \%$

$-21 \%$

9\%

$30 \%$

$-50 \%$

$0 \%$

$-91 \%$

$-6 \%$

$-23 \%$

$-83 \%$

$-33 \%$

$82 \%$

Source: Cedefop European Skills and Jobs (ESJ) survey 


\section{Annex: Definitions of main variables}

\begin{tabular}{|c|c|}
\hline Variable & Definition \\
\hline overeducated & $\begin{array}{l}\text { D: } 1 \text { if respondent's highest level of education attained is greater than the qualification } \\
\text { level needed to do the job; } 0 \text { otherwise }\end{array}$ \\
\hline \multicolumn{2}{|l|}{$\begin{array}{l}\text { Human capital } \\
\text { characteristics }\end{array}$} \\
\hline age & $\begin{array}{l}\text { C: age of respondent derived as difference between year of survey and declared date of } \\
\text { birth in survey }\end{array}$ \\
\hline agesq & C: Quadratic age term \\
\hline male & D: 1 if male; 0 if female \\
\hline preveduc & D: Main activity before start of work with current employer was 'In education or training' \\
\hline prevunemp & D: Main activity before start of work with current employer was 'Unemployed' \\
\hline prevoth & $\begin{array}{l}\text { D: Main activity before start of work with current employer was 'Other-not working (e.g. } \\
\text { child care, family responsibilities, injury, disability)' }\end{array}$ \\
\hline prevemp (reference) & D: Main activity before start of work with current employer was 'Employed in another job’ \\
\hline teacher & $\begin{array}{l}\text { D: Main area or field of the highest qualification is: 'Teacher training and education } \\
\text { sciences' }\end{array}$ \\
\hline humanities & D: Main area or field of the highest qualification is: 'Humanities, languages and arts' \\
\hline econ & $\begin{array}{l}\text { D: Main area or field of the highest qualification is: 'Economics, Business, Law or } \\
\text { Finance' }\end{array}$ \\
\hline othersocial & D: Main area or field of the highest qualification is: 'Other social sciences' \\
\hline natural & D: Main area or field of the highest qualification is: 'Natural sciences’ \\
\hline maths & D: Main area or field of the highest qualification is: 'Mathematics and statistics' \\
\hline ict & D: Main area or field of the highest qualification is: 'Computing sciences’ \\
\hline engineering & D: Main area or field of the highest qualification is: 'Engineering sciences’ \\
\hline agri & D: Main area or field of the highest qualification is: 'Agriculture and veterinary sciences’ \\
\hline medicine & D: Main area or field of the highest qualification is: 'Medicine and health-related sciences' \\
\hline service & $\begin{array}{l}\text { D: Main area or field of the highest qualification is: 'Security, transport or personal } \\
\text { services' }\end{array}$ \\
\hline otherfield (reference) & D: Main area or field of the highest qualification is: 'Other specific subject area’ \\
\hline emptenure & $\begin{array}{l}\text { C: years of tenure with current employer; derived by the question: 'how many years in total } \\
\text { have you been working for your current employer?' }\end{array}$ \\
\hline emptenuresq & C: years of employer tenure squared \\
\hline train_courses_in & $\begin{array}{l}\text { D: In the last } 12 \text { months (since started your job if tenure less than } 12 \text { months) respondent } \\
\text { has undergone 'training courses attended mostly or only during work hours' }\end{array}$ \\
\hline train_courses_out & $\begin{array}{l}\text { D: In the last } 12 \text { months (since started your job if tenure less than } 12 \text { months) respondent } \\
\text { has undergone 'training courses attended mostly or only outside of work hours' }\end{array}$ \\
\hline train_ojt & $\begin{array}{l}\text { D: In the last } 12 \text { months (since started your job if tenure less than } 12 \text { months) respondent } \\
\text { has undergone 'training courses whilst performing your regular job (e.g. instruction by } \\
\text { supervisor/co-worker; job rotation; peer support; quality circles)' }\end{array}$ \\
\hline train_no (reference) & $\begin{array}{l}\text { D: In the last } 12 \text { months (since started your job if tenure less than } 12 \text { months) respondent } \\
\text { has 'Not undergone any training' }\end{array}$ \\
\hline overskilled & D: 1 if respondent's skills are higher than needed to do the job; 0 otherwise \\
\hline skilldef & $\begin{array}{l}\text { C: Measure of respondent's skill deficit, derived as the difference between the respondent's } \\
\text { own skill level, assessed on a } 0-100 \text { scale, and a value of } 100 \text { defined as the level needed to } \\
\text { do the job as well as possible. }\end{array}$ \\
\hline \multicolumn{2}{|l|}{ Job characteristics } \\
\hline temporary & D: Type of employment contract in current job: 'A fixed-term/temporary contract' \\
\hline informal & D: Type of employment contract in current job: ‘No formal contract' \\
\hline indefinite (reference) & D: Type of employment contract in current job: 'Indefinite/permanent contract’ \\
\hline multisite & $\begin{array}{l}\text { D: } 1 \text { if respondent works for organisation with more than one workplace (e.g. a branch or } \\
\text { local unit); } 0 \text { otherwise }\end{array}$ \\
\hline private & D: 1 if respondent works in a private company or partnership; 0 otherwise \\
\hline size1to9 (reference) & D: 1 if number of people who work in the respondent's workplace is: $1-9$ \\
\hline
\end{tabular}




\begin{tabular}{|c|c|}
\hline size10to49 & D: 1 if number of people who work in the respondent's workplace is: $10-49$ \\
\hline size50to99 & D: 1 if number of people who work in the respondent's workplace is: 50-99 \\
\hline size100to249 & D: 1 if number of people who work in the respondent's workplace is: $100-249$ \\
\hline size250to499 & D: 1 if number of people who work in the respondent's workplace is: $250 \_499$ \\
\hline size500 & D: 1 if number of people who work in the respondent's workplace is: 500 and over \\
\hline jobnrout & $\begin{array}{l}\text { D: } 1 \text { if respondent's job involves, if at all, 'responding to non-routine situations during the } \\
\text { course of the daily work' }\end{array}$ \\
\hline joblearn & D: 1 if respondent's job involves, if at all, 'learning new things' \\
\hline jobaut & $\begin{array}{l}\text { D: } 1 \text { if respondent's job involves, if at all, 'choosing him/herself the way in which to do the } \\
\text { work' }\end{array}$ \\
\hline jobteam & D: 1 if respondent's job involves, if at all, 'working as part of a team' \\
\hline role_promoted & $\begin{array}{l}\text { D: } 1 \text { if respondent was promoted to a higher level position since he/she started working for } \\
\text { the current employer; } 0 \text { otherwise }\end{array}$ \\
\hline \multicolumn{2}{|l|}{ Job-skill needs } \\
\hline advlit & $\begin{array}{l}\text { D: } 1 \text { if the highest level of literacy skills required for doing the respondent's job is: } \\
\text { advanced literacy (e.g. writing long documents such as reports, handbooks, articles or } \\
\text { books); } 0 \text { if basic literacy (e.g. reading manuals, procedures, letters or memos) }\end{array}$ \\
\hline advnum & $\begin{array}{l}\text { D: } 1 \text { if the highest level of literacy skills required for doing the respondent's job is: } \\
\text { advanced numeracy (e.g. calculations using advanced mathematical or statistical } \\
\text { procedures); } 0 \text { if basic numeracy (calculations using decimals, percentages or fractions, } \\
\text { understanding tables or graphs) }\end{array}$ \\
\hline basicict (reference) & $\begin{array}{l}\text { D: } 1 \text { if the highest level of Information, Communication and Technology skills required for } \\
\text { doing the respondent’s job is: Basic ICT (e.g. using a PC, tablet or mobile device for email; } \\
\text { or internet browsing) }\end{array}$ \\
\hline modict & $\begin{array}{l}\text { D: } 1 \text { if the highest level of Information, Communication and Technology skills required for } \\
\text { doing the respondent's job is: Moderate ICT (e.g. word-processing; using or creating } \\
\text { documents and spreadsheets); } 0 \text { otherwise }\end{array}$ \\
\hline advict & $\begin{array}{l}\text { D: } 1 \text { if the highest level of Information, Communication and Technology skills required for } \\
\text { doing the respondent's job is: Advanced ICT (e.g. developing software, applications or } \\
\text { programming; using computer syntax); } 0 \text { otherwise }\end{array}$ \\
\hline highiskill & $\begin{array}{l}\text { C (0-10 scale): an additive scale ranking the importance of a set of soft skills } \\
\text { (communication, team-working, foreign language, customer handling, problem solving, } \\
\text { learning to learn, planning and organisation) for doing the respondent's job based on } \\
\text { question: 'How important are the following skills for doing your job?': }\end{array}$ \\
\hline \multicolumn{2}{|l|}{ Job motives } \\
\hline factor_suitskills & $\begin{array}{l}\text { C (0-10 scale): Importance of factor in respondent's decision to accept the current job: } \\
\text { 'The job suited your qualifications and skills' }\end{array}$ \\
\hline factor_experience & $\begin{array}{l}\text { C (0-10 scale): Importance of factor in respondent's decision to accept the current job: } \\
\text { 'You wanted to gain some work experience' }\end{array}$ \\
\hline factor_security & $\begin{array}{l}\text { C (0-10 scale): Importance of factor in respondent's decision to accept the current job: 'The } \\
\text { job provided security' }\end{array}$ \\
\hline factor_career & $\begin{array}{l}\text { C (0-10 scale): Importance of factor in respondent's decision to accept the current job: 'The } \\
\text { job offered good career progression and development' }\end{array}$ \\
\hline factor_reputation & $\begin{array}{l}\text { C (0-10 scale): Importance of factor in respondent's decision to accept the current job: 'The } \\
\text { company/organisation was well known/respected in its field' }\end{array}$ \\
\hline factor_benefits & $\begin{array}{l}\text { C (0-10 scale): Importance of factor in respondent's decision to accept the current job: 'The } \\
\text { pay and package of fringe benefits (e.g. health insurance, bonuses) was good' }\end{array}$ \\
\hline factor_closehome & $\begin{array}{l}\text { C (0-10 scale): Importance of factor in respondent's decision to accept the current job: 'The } \\
\text { job was close to home' }\end{array}$ \\
\hline factor_intrinsic & $\begin{array}{l}\text { C ( } 0-10 \text { scale): Importance of factor in respondent's decision to accept the current job: } \\
\text { 'You were interested in the nature of the work itself' }\end{array}$ \\
\hline factor_worklife & $\begin{array}{l}\text { C (0-10 scale): Importance of factor in respondent's decision to accept the current job: 'The } \\
\text { job had a good work-life balance' }\end{array}$ \\
\hline
\end{tabular}

NB: $\mathrm{D}$ = dummy variable; $\mathrm{C}$ = continuous variable 